DOI: 10.1002/chem.200((will be filled in by the editorial staff))

"This is the peer reviewed version of the following article: Chem. Eur. J. 2014, 20, 2264-2275, which has been published in final form at https://doi.org/10.1002/chem.201302536. This article may be used for non-commercial purposes in accordance with Wiley Terms and Conditions for Self-Archiving published at http://olabout.wiley.com/WileyCDA/Section/id-820227.html." 


\title{
Highly Active Aluminium Catalysts for the Formation of Organic Carbonates from $\mathrm{CO}_{2}$ and Oxiranes
}

\author{
Christopher J. Whiteoak, ${ }^{[a]}$ Nicola Kielland, ${ }^{[a]}$ Victor Laserna, ${ }^{[a]}$ Fernando Castro-Gómez, ${ }^{[a]}$ Eddy \\ Martin, ${ }^{[a]}$ Eduardo C. Escudero-Adán, ${ }^{[\mathrm{a}]}$ Carles Bo, ${ }^{[\mathrm{a}][c]}$ and Arjan W. Kleij*[a,b]
}

\begin{abstract}
Al}^{\mathrm{III}}$ complexes of aminotris-phenolate ligand scaffolds have been prepared in order to attain highly Lewis acidic catalysts. Combination of the aforementioned systems with ammonium halides provides highly active catalysts for the synthesis of organic carbonates through addition of carbon dioxide to oxiranes with initial turnover frequencies among the highest

reported to date within the context of cyclic carbonate formation. Density functional theory (DFT) studies combined with kinetic data provides a rational for the relative high activity found for these $\mathrm{Al}^{\mathrm{III}}$ complexes, and data are consistent with a monometallic mechanism. The activity and versatility of these $\mathrm{Al}^{\mathrm{III}}$ complexes has also been evaluated against some state-of-the-art
\end{abstract}

catalysts and the combined results compare favorably in terms of catalyst construction, stability, activity and applicability.

Keywords: aluminium • catalysis • carbon dioxide $\bullet$ organic carbonates - homogeneous catalysis

\section{Introduction}

The use of carbon dioxide $\left(\mathrm{CO}_{2}\right)$ as a renewable carbon feedstock is of both academic and industrial relevance. ${ }^{[1]}$ However, there are only a limited number of chemical processes that have been successfully developed where $\mathrm{CO}_{2}$ is used as a reagent ${ }^{[2]}$ and even less that classify as truly sustainable from the point view of energy use and carbon recycling. ${ }^{[3]}$ One method of increasing the sustainability of a chemical process is through the use of catalysis and therefore use of such may enable the realization of truly sustainable $\mathrm{CO}_{2}$ conversions. ${ }^{[4]}$ The largest challenge in $\mathrm{CO}_{2}$ conversion is its relative high kinetic and thermodynamic stability; whereas catalysis can be used to effectively lower the barriers associated with the kinetic stability, the choice for higher-energy substrates can help to overcome the thermodynamic hurdle. With this latter aspect in mind, the use of epoxides (oxiranes) has the advantage that ring-strain is released upon ring-opening and its conversion in the presence of $\mathrm{CO}_{2}$ providing either organic poly${ }^{[5]}$ or cyclic carbonates ${ }^{[6]}$ (Scheme 1) is indeed exothermic. This addition $^{[7]}$ of $\mathrm{CO}_{2}$ to epoxides is a well-documented area of research where a number of different catalytic solutions have been proposed using ionic liquids, ${ }^{[8]}$ binary ${ }^{[9]}$ or bifunctional (metallosalen) complexes, ${ }^{[10]}$ and simple organic motifs such as "onium salts". ${ }^{[11]}$ However, only in a limited amount of cases have these catalytic efforts resulted in systems with (very) high activities expressed in high turnover frequencies (TOFs) and high turnover numbers (TONs).

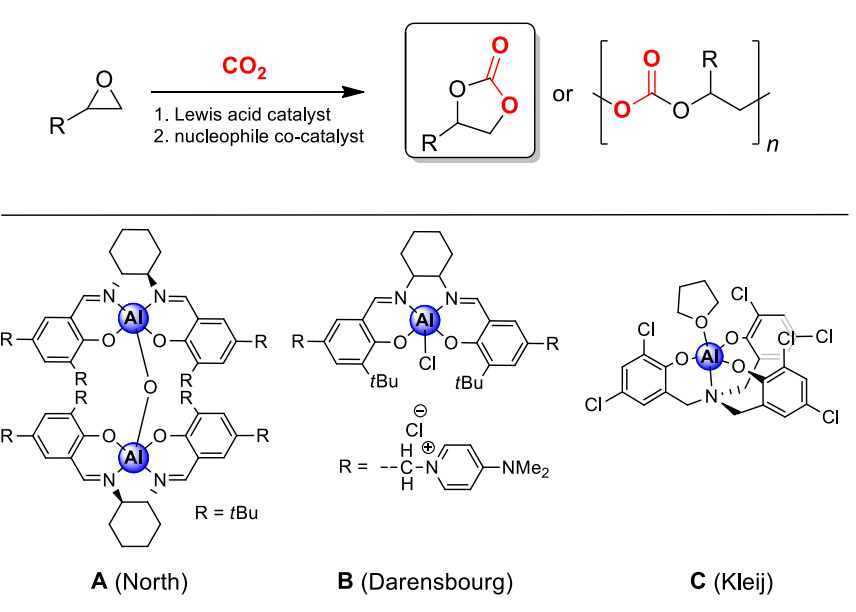

Scheme 1. Top: addition of $\mathrm{CO}_{2}$ to epoxides yielding cyclic- and poly-carbonates and below some reported successful catalyst systems (A-C) based on aluminium for this reaction. Note that catalyst systems $\mathbf{A}$ and $\mathbf{C}$ are binary systems and are combined with $\mathrm{NBu}_{4} \mathrm{X}(\mathrm{X}=\mathrm{Br}$ or $\mathrm{I})$ whereas catalyst $\mathbf{B}$ is a one-component, bifunctional system.

[a] Dr. C. J. Whiteoak, Dr. N. Kielland, V. Laserna, F. Castro-Gómez, Dr. E.

Martin, E. Escudero-Adán, Prof.C. Bo, Prof. Dr. A. W. Kleij

Institute of Chemical Research of Catalonia (ICIQ)

Av. Països Catalans 16, 43007 Tarragona, Spain

Fax: (+34)-977-920-828

E-mail: akleij@iciq.es

[b] Prof. Dr. A. W. Kleij

Catalan Institute of Research and Advanced Studies (ICREA)

Pg. Lluís Companys 23, 08010 Barcelona, Spain

[c] Prof. Dr. C. Bo, Departament de Química Física i Inorgánica, Universitat Rovira i Virgili, Marcel·lí Domingo s/n 43007 Tarragona (Spain)

Supporting information for this article is available on the WWW under http://www.chemeurj.org/ or from the author. 
In addition, when taking into account possible application of catalysts in an industrial setting ${ }^{[12]}$ long-term stability, recycling features, accessibility, cost-effectiveness, toxicity and catalyst modularity are features that are of crucial importance.

Recently, Ema, Sakai and co-workers reported on bifunctional metalloporphyrin catalysts $(\mathrm{M}=\mathrm{Mg}, \mathrm{Zn})$ that were able to produce cyclic carbonates based on terminal epoxides with high TOFs of up to $12,000 \mathrm{~h}^{-1}$ and TONs up to $103,000 .^{[10 \mathrm{~b}]}$ This work inspired us to design and construct catalyst systems with similar or even improved potential in this area with a focus on high reactivity and wide application potential (substrate scope). We became interested in using amino-tris-phenolate scaffolds ${ }^{[9 b, 13 a]}$ as ligand alternatives for the widely used salen and/or salans, ${ }^{[14]}$ as these provide different molecular conformations upon complexation of suitable metal ions. ${ }^{[13]}$ We envisioned that the presence of fewer donor atoms in the plane of the metal would be beneficial for those cases where the steric requirement of the coordinating epoxide substrate would limit catalytic turnover. As in the majority of cases binary catalyst systems are employed (i.e., a metal complex combined with a suitable nucleophile), the nucleophile needed in the ring-opening step of the coordinated epoxide would have difficulty approaching the substrate and entering the coordination sphere of the metal. We have recently reported that $\mathrm{Fe}^{\mathrm{III}}$-based amino-tris-phenolate complexes are efficient catalysts for the formation of a wide series of cyclic carbonates under virtually ambient conditions $\left(25^{\circ} \mathrm{C}, p \mathrm{CO}_{2}=2\right.$ bar $)$ and also effectively mediate the conversion of internal epoxides. ${ }^{[\mathrm{b}]}$ Further to that, computational analyses ${ }^{[15]}$ on the $\mathrm{Zn}$ (salphen) mediated formation of cyclic carbonates ${ }^{[4 \mathrm{c}, 9 \mathrm{e}]}$ have indicated that metallosalen catalyst systems may have limitations concerning the more sterically demanding substrates. The fact that amino-tris-phenolate complexes show better catalytic potential is in line with these theoretical studies.

In an attempt to create even more powerful catalyst systems, we have turned our focus to aluminium (Al) systems, as recent literature has demonstrated that complexes based on $\mathrm{Al}$ can be attractive within the context of organic carbonate formation (Scheme 1; see systems A-C) ${ }^{[16]}$ Our preliminary results using an $\mathrm{Al}$ (amino-tris-phenolate) complex (Scheme 1, C) demonstrated unprecedented activity (initial TOFs up to $36,000 \mathrm{~h}^{-1}$ and TONs exceeding 118.000) and substrate scope; ${ }^{[17]}$ here we will demonstrate that these kind of complexes based on this earth-abundant metal can be easily fine-tuned giving rise to catalyst systems with activities among the highest reported to date. Further theoretical, kinetic, stability and structural studies are also presented that clearly show a combination of attractive properties for these powerful catalyst systems during $\mathrm{CO}_{2}$ conversion into value-added commodities such as cyclic carbonates. Computational investigations have shed important insight on reasons for the observation of high activities of these new Al-based catalysts.

\section{Results and Discussion}

Synthesis and analysis of complexes: The amino-tris-phenol ligands 1-2 were prepared by a known Mannich condensation reaction, ${ }^{[18]}$ whereas $\mathbf{3}$ was prepared in step-wise way. ${ }^{[19]}$ The ligand bearing chloride substituents (4) has been reported by Kol and co-workers ${ }^{[20]}$ but the preparation was achieved using a different work-up procedure to that reported; after refluxing 2,4-dichlorophenol and hexamethyltetramine (HMTA) together at $110^{\circ} \mathrm{C}$ for $2.5 \mathrm{~h}$, an (unexpected) adduct of HMTA and the desired ligand, 4.HMTA, was isolated (X-ray structure, see Supporting Information). The HMTA could be removed by an acid/base work-up to yield the desired ligand
4 in good purity although low yield. This ligand is difficult to prepare selectively as a result of the poor solubility of both the corresponding amino-bis-phenol and the amino-tris-phenol in the reaction medium. Upon formation of the amino-tris-phenol ligands, a degradation may occur towards the amino-bis-phenol as reported by Solomon and coworkers for ligand $\mathbf{1}^{[21]}$ In the case of $\mathbf{4}$ this degradation reaction appears to be rapid as the poor solubility of the amino-bis-phenol drives the equilibrium towards this undesired product as soon as the amino-tris-phenol is obtained, thereby limiting the yield of the desired ligand.

The Al(amino-tris-phenolate) complexes were obtained through the reaction of the ligand precursors 1-4 with trimethylaluminium $\left(\mathrm{AlMe}_{3}\right)$ in THF (Scheme 2). The characterization data for complexes $\mathbf{1}, \mathbf{2}$ and $\mathbf{4}$ are consistent with monomeric complexes, whereby a THF ligand occupies the apical position of a trigonal bipyrimidal coordination geometry. Complex $\mathbf{7}$ is presumed to exist as a dimeric species (as is its $\mathrm{Fe}(\mathrm{III})$ analogue) $)^{[13]}$ considering its lower solubility in most solvents. The molecular structure for $\mathbf{8} \cdot$ THF (Figure 1) was determined by X-ray crystallography from crystals obtained from $\mathrm{THF} /$ hexane. The molecular structures of $\mathbf{5} \cdot \mathrm{THF}$ and $\mathbf{6} \cdot \mathrm{THF}$ were reported previously. ${ }^{[22]}$

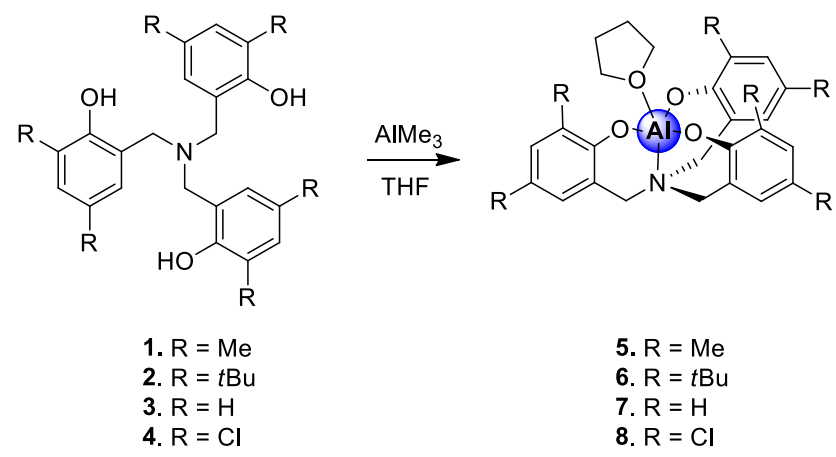

Scheme 2. Synthesis of Al(amino-tris-phenolate) complexes 5-8 from precursor ligands $1-4$

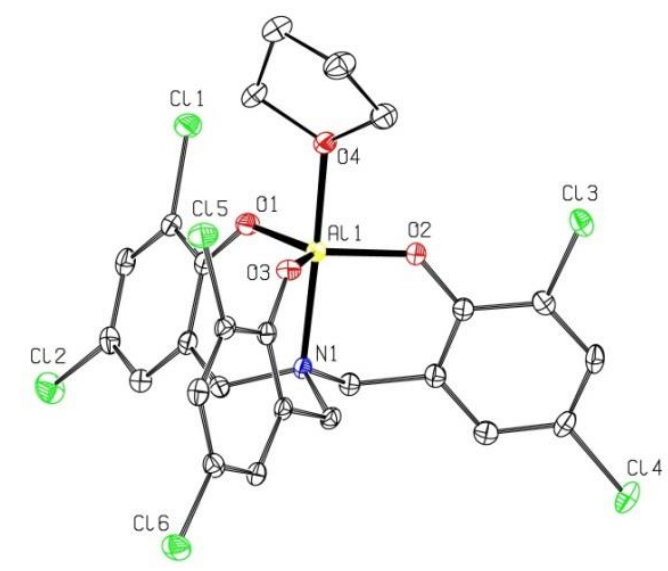

Figure 1. Displacement ellipsoid plot of the molecular structure of 8. THF together with a partial numbering scheme. Co-crystallized solvent molecules and rotational disorder in the THF ligand is omitted for clarity. Selected bond distances $[\AA]$ and angles [ $\left.{ }^{\circ}\right]$ : $\mathrm{Al}(1)$ $\mathrm{O}(1)=1.7604(14), \mathrm{Al}(1)-\mathrm{O}(2)=1.7527(15), \mathrm{Al}(1)-\mathrm{O}(3)=1.7689(15), \mathrm{Al}(1)-\mathrm{O}(4)=$ 1.9216(15), $\mathrm{Al}(1)-\mathrm{N}(1)=2.0715(17) ; \mathrm{O}(4)-\mathrm{Al}(1)-\mathrm{N}(1)=178.11(7), \mathrm{O}(1)-\mathrm{Al}(1)-\mathrm{O}(2)=$ $120.94(7), \mathrm{O}(2)-\mathrm{Al}(1)-\mathrm{O}(3)=117.02(7), \mathrm{O}(1)-\mathrm{Al}(1)-\mathrm{O}(4)=87.31(7), \mathrm{O}(2)-\mathrm{Al}(1)-\mathrm{O}(4)=$ $89.50(7), \mathrm{N}(1)-\mathrm{Al}(1)-\mathrm{O}(1)=90.94(7), \mathrm{N}(1)-\mathrm{Al}(1)-\mathrm{O}(3)=91.43(7)$ 
Further fine-tuning of the amino-tris-phenol scaffold can also be accomplished through the synthesis of nonsymmetrical ligands. In this respect, amino-bis-phenols (i.e. a secondary amine) may serve as a suitable precursor, since simple alkylation of the amine with an appropriate reagent directly affords nonsymmetrical systems. This was probed for the secondary amine $\mathbf{9}^{[23]}$ which was alkylated with the commercially available alkyl bromide 10; the desired nonsymmetrical amino-tris-phenol ligand $\mathbf{1 1}$ was isolated in $68 \%$ yield. Metalation, as described for Al-complexes 5-8, was achieved similarly to furnish $\mathbf{1 2}$ in $78 \%$ yield. The identity of $\mathbf{1 2}$ was first established by ${ }^{1} \mathrm{H}$ NMR (details in the Supporting Information) and further affirmed by X-ray crystallography (Figure 2). The structure reported for $\mathbf{1 2}$ represents to our knowledge the first crystallographically characterized nonsymmetrical amino-trisphenolate complex.<smiles>CC(C)(C)c1cc(CNCc2cc(C(C)(C)C)cc(C(C)(C)C)c2O)c(O)c(C(C)(C)C)c1</smiles><smiles>CC(C)(C)c1cc(CN(Cc2cc(C(C)(C)C)cc(C(C)(C)C)c2O)Cc2cc(C(C)(C)C)cc(C(C)(C)C)c2O)c(O)c(C(C)(C)C)c1</smiles>

Scheme 3. Synthesis of nonsymmetrical Al(amino-tris-phenolate) complex 12.

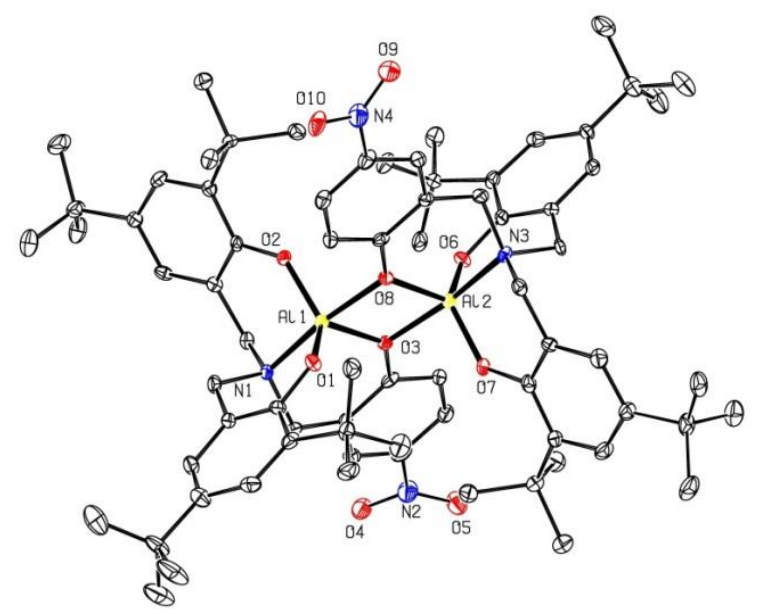

Figure 2. Displacement ellipsoid plot of the dimeric structure of $\mathbf{1 2}$ together with a partia numbering scheme. Co-crystallized solvent molecules and rotational disorder are omitted for clarity. The bond lengths/angles around both $\mathrm{Al}$ centres are rather similar. Selected bond distances $[\AA]$ and angles $\left[{ }^{\circ}\right]: \mathrm{Al}(1)-\mathrm{O}(1)=1.740(3), \mathrm{Al}(1)-\mathrm{O}(2)=1.734(3), \mathrm{Al}(1)-$ $\mathrm{O}(3)=1.846(2), \mathrm{Al}(1)-\mathrm{O}(8)=1.948(2), \mathrm{Al}(1)-\mathrm{N}(1)=2.003(3) ; \mathrm{O}(1)-\mathrm{Al}(1)-\mathrm{O}(2)=$ 124.28(13), O(1)-Al(1)-O(3) = 115.08(12), O(1)-Al(1)-O(8) = 91.15(11), O(1)-Al(1)$\mathrm{N}(1)=93.50(12), \mathrm{O}(2)-\mathrm{Al}(1)-\mathrm{O}(8)=91.14(11), \mathrm{O}(3)-\mathrm{Al}(1)-\mathrm{O}(8)=76.99(10), \mathrm{Al}(1)-$ $\mathrm{O}(8)-\mathrm{Al}(2)=39.94(8), \mathrm{Al}(1)-\mathrm{O}(8)-\mathrm{Al}(2)-\mathrm{O}(3)=176.71(18)$

Complex 12 crystallized as a dimeric structure comprising two $\mu_{2-}$ phenoxo bridges. Such dimerization potential has been well-
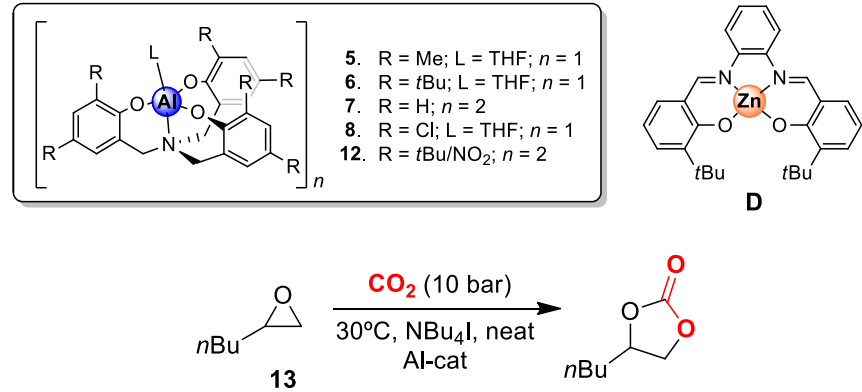

Table 1. Initial catalysis results obtained for the synthesis of the cyclic carbonate derived from 1,2 -epoxyhexane at $30^{\circ} \mathrm{C}$ using $\mathrm{NBu}_{4} \mathrm{I}$ as co-catalyst. ${ }^{[\mathrm{a}] \mathrm{b}]}$

\begin{tabular}{|c|c|c|c|c|c|}
\hline Entry & Cat. & $\begin{array}{l}\text { Cat. } \\
\text { (mol\%) }\end{array}$ & $\begin{array}{l}\text { Co-cat. } \\
\text { (mol\%) }\end{array}$ & $\begin{array}{l}\text { Conv. } \\
(\%)^{[c]}\end{array}$ & $\begin{array}{l}\text { TOF } \\
\left(\mathrm{h}^{-1}\right)^{[\mathrm{d}]}\end{array}$ \\
\hline 1 & 5 & 0.5 & 0 & 0 & 0 \\
\hline 2 & 5 & 0.05 & 0.25 & 6 & 60 \\
\hline 3 & 5 & 0.5 & 2.5 & 74 & 74 \\
\hline 4 & 5 & 0.7 & 2.5 & 94 & 67 \\
\hline 5 & 6 & 0.05 & 0.25 & 5 & 50 \\
\hline 6 & 6 & 0.5 & 2.5 & 65 & 65 \\
\hline 7 & 6 & 0.7 & 2.5 & 83 & 59 \\
\hline 8 & 7 & 0.05 & 0.25 & 2 & 20 \\
\hline 9 & 7 & 0.5 & 2.5 & 18 & 18 \\
\hline 10 & 8 & 0.5 & 0 & 0 & 0 \\
\hline 11 & 8 & 0.05 & 0.25 & 10 & 100 \\
\hline 12 & 8 & 0.5 & 2.5 & 91 & 91 \\
\hline 13 & 12 & 0.05 & 0.25 & 4 & 40 \\
\hline 14 & 12 & 0.5 & 2.5 & 27 & 27 \\
\hline 15 & - & - & 0.25 & 0 & - \\
\hline 16 & - & - & 2.5 & 0 & - \\
\hline 17 & D & 0.5 & 2.5 & 46 & 46 \\
\hline 18 & A & 0.5 & 2.5 & 6 & 6 \\
\hline 19 & A & 0.5 & $2.5^{[\mathrm{e}]}$ & 50 & 50 \\
\hline
\end{tabular}

[a] Reaction conditions: $1.0 \mathrm{~g}$ 1,2-epoxyhexane $(9.98 \mathrm{mmol}), 1.0 \mathrm{MPa} \mathrm{CO}_{2}$ initial pressure, $2 \mathrm{~h}, 30^{\circ} \mathrm{C}$. [b] Catalyst concentration calculated on a per $\mathrm{Al}$ atom basis and amount related to the substrate. [c] Determined by ${ }^{1} \mathrm{H}$ NMR spectroscopy of the crude reaction mixture; selectivity in all cases $>99 \%$. Conversions were found to be reproducible within $\pm 2 \%$ in four independent runs for selected experiments. [d] Average turn-over frequency $\left(\mathrm{TOF} / \mathrm{h}\right.$ ) during the first $2 \mathrm{~h}$. [e] Using $\mathrm{NBu}_{4} \mathrm{Br}$ as co-catalyst. 
documented in the literature and recently we have shown that dimers of Fe(amino-tris-phenolate) complexes can be easily disrupted by addition of a suitable, competing ligand (THF, pyridine) or substrate (epoxide) ${ }^{[9 b, 13]}$ providing monomeric species which is a prerequisite for application in catalysis (vide infra).

Catalysis screening with Al complexes 5-8 and 12: The catalytic potential of the $\mathrm{Al}$ complexes was first evaluated under mild conditions $\left(\mathrm{T}=30^{\circ} \mathrm{C}, p\left(\mathrm{CO}_{2}\right)=1.0 \mathrm{MPa}=10\right.$ bar $)$ using $1,2-$ epoxyhexane (13) as benchmark substrate and $\mathrm{NBu}_{4} \mathrm{I}$ as co-catalyst (Table 1, entries 1-14). In general, at catalyst loadings of $0.05 \mathrm{~mol} \%$ low conversions were noted, while increasing this by at least ten-fold (0.5-0.7 mol\%) resulted in high conversion levels of up to $94 \%$ (entry 3). The Al-complexes themselves proved to be inactive (entries 1 and 10). The best result, in terms of initial TOF, was obtained for $\mathrm{Al}$ complex 8 (entry 11) which gave an average TOF of $100 \mathrm{~h}^{-1}$. It should be noted that the co-catalyst alone $\left(\mathrm{NBu}_{4} \mathrm{I}\right)$ under similar conditions reported for the $\mathrm{Al}$ complexes (either at 0.05 or $0.5 \mathrm{~mol} \%$ catalyst loading) proved to be ineffective and no conversion into carbonate was detected (entries 15 and 16). Further to that, upon comparison with two benchmark catalyst systems (North's bimetallic Al(salen) A combined with $\mathrm{NBu}_{4} \mathrm{I}$ (entry 18) or $\mathrm{NBu}_{4} \mathrm{Br}$ (entry 19) and our previously reported $\mathrm{Zn}$ (salphen) catalyst $\mathbf{D}$ ) we found that these latter systems were less effective and showed about half the activity (TOFs are $50 \mathrm{~h}^{-1}$ and $46 \mathrm{~h}^{-1}$, respectively; entries 17 and-19) compared with $\mathrm{Al}$ complex 8 at the same metal loading (entry 12; TOF $=91 \mathrm{~h}^{-1}$ ). ${ }^{[24]}$ The lowest activities (expressed in initial TOFs) were found for the non-substituted $\mathrm{Al}$ complex 7 and the nonsymmetrical $\mathrm{Al}$ complex 12. It is known that these complexes have higher tendency to form dimeric structures which can compete with the required substrate coordination. Temperature is an important factor controlling the monomer-dimer equilibrium with higher temperatures favoring higher concentrations of the more reactive monomeric species. ${ }^{[13]}$ Therefore, in order to compare and evaluate better the catalytic potential of $\mathrm{Al}$ complexes 5-8 and $\mathbf{1 2}$ we then focused on higher reaction temperatures to further increase the turnover frequencies (Table 2).

For this second stage of the catalysis screening, temperatures up to $110^{\circ} \mathrm{C}$ were considered and $\mathrm{Al}$ complexes $\mathbf{5 - 8}$ were utilized as their substitution pattern allows for a direct comparison of activities within this series. As expected, at higher temperatures complexes 5-8 display higher reactivity and an increase in the observed average TOFs for all complexes, with the complexes in the absence of $\mathrm{NBu}_{4} \mathrm{I}$ being inactive (entries 3 and $17 ; 90^{\circ} \mathrm{C}$ ). For instance, for $\mathrm{Al}$ complex 5 at $50^{\circ} \mathrm{C}$ an increase in the TOF is noted to $410 \mathrm{~h}^{-1}$ and reaching 2200 $\mathrm{h}^{-1}$ at $110^{\circ} \mathrm{C}$ at a catalyst loading of only $0.005 \mathrm{~mol} \%$ (Table 2, entries 1-5). For the other catalysts $\mathbf{6 - 8}$ similar features were noted, i.e. an increase in the TOF with the highest reactivity was noted at $110^{\circ} \mathrm{C}$. The $\mathrm{Al}$ complex $\mathbf{7}$ which is likely to form (at least in part) a dimeric structure in solution shows, as expected, higher reactivity at higher temperatures as a result of a more favorable monomer-dimer equilibrium. $^{[13]}$ Nonetheless, clearly for $\mathrm{Al}$ complex $\mathbf{8}$ at all temperatures the highest TOFs were observed suggesting that this system has the highest catalytic potential with a notable TOF of up to $2600 \mathrm{~h}^{-1}$ (entry 20).

At increased reaction temperatures there are two crucial features to consider: first, at elevated temperatures the efficacy of the cocatalyst alone (i.e., the ammonium salt) ${ }^{[11]}$ is needed for comparison. ${ }^{[25]}$ Critical assessment of the conversion data at $110^{\circ} \mathrm{C}$ shows that the absence/presence of any Al complex (entries 5, 10,

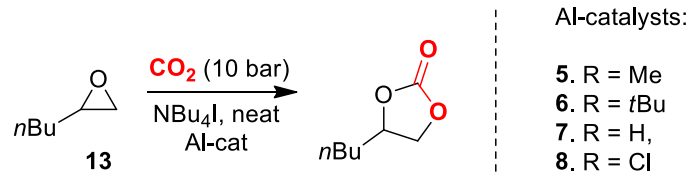

Table 2. Catalysis results obtained for the synthesis of the cyclic carbonate derived from 1,2-epoxyhexane at various temperatures using $\mathrm{NBu}_{4} \mathrm{I}$ as co-catalyst. ${ }^{[a][b]}$

\begin{tabular}{|c|c|c|c|c|c|c|}
\hline Entry & Cat. & $\begin{array}{c}\text { Cat. } \\
\text { (mol\%) }\end{array}$ & $\begin{array}{l}\text { Co-cat. } \\
\text { (mol\%) }\end{array}$ & $\begin{array}{c}\mathrm{T} \\
\left({ }^{\circ} \mathrm{C}\right)\end{array}$ & $\begin{array}{l}\text { Conv. } \\
(\%)^{[c]}\end{array}$ & $\begin{array}{l}\text { TOF } \\
\left(\mathrm{h}^{-1}\right)^{[\mathrm{d}]}\end{array}$ \\
\hline 1 & 5 & 0.05 & 0.25 & 50 & 41 & 410 \\
\hline 2 & 5 & 0.05 & 0.25 & 70 & 60 & 600 \\
\hline 3 & 5 & 0.05 & 0 & 90 & 0 & 0 \\
\hline 4 & 5 & 0.05 & 0.25 & 90 & 89 & 890 \\
\hline 5 & 5 & 0.005 & 0.025 & 110 & 22 & 2200 \\
\hline 6 & 6 & 0.05 & 0.25 & 50 & 20 & 200 \\
\hline 7 & 6 & 0.05 & 0.25 & 70 & 52 & 520 \\
\hline 8 & 6 & 0.05 & 0.25 & 90 & 74 & 740 \\
\hline 9 & 6 & 0.01 & 0.05 & 90 & 23 & 1150 \\
\hline 10 & 6 & 0.005 & 0.025 & 110 & 17 & 1700 \\
\hline 11 & 7 & 0.05 & 0.25 & 50 & 15 & 150 \\
\hline 12 & 7 & 0.05 & 0.25 & 70 & 58 & 580 \\
\hline 13 & 7 & 0.05 & 0.25 & 90 & 78 & 780 \\
\hline 14 & 7 & 0.005 & 0.025 & 110 & 21 & 2100 \\
\hline 15 & 8 & 0.05 & 0.25 & 50 & 41 & 410 \\
\hline 16 & 8 & 0.05 & 0.25 & 70 & 82 & 820 \\
\hline 17 & 8 & 0.05 & 0 & 90 & 0 & 0 \\
\hline 18 & 8 & 0.05 & 0.25 & 90 & 96 & 960 \\
\hline 19 & 8 & 0.01 & 0.05 & 90 & 42 & 2100 \\
\hline 20 & 8 & 0.005 & 0.025 & 110 & 26 & 2600 \\
\hline 21 & - & - & 0.25 & 50 & 2 & - \\
\hline 22 & - & - & 0.25 & 70 & 15 & - \\
\hline 23 & - & - & 0.25 & 90 & 17 & - \\
\hline 24 & - & - & 0.025 & 110 & 22 & - \\
\hline
\end{tabular}

[a] Reaction conditions: $1.0 \mathrm{~g}$ 1,2-epoxyhexane $(9.98 \mathrm{mmol}), 1.0 \mathrm{MPa} \mathrm{CO}_{2}$ initial pressure, $2 \mathrm{~h}$. [b] Catalyst concentration calculated on a per $\mathrm{Al}$ atom basis and amount 
related to the substrate. [c] Determined by ${ }^{1} \mathrm{H}$ NMR spectroscopy of the crude reaction mixture; selectivity in all cases $>99 \%$. Conversions were found to be reproducible within $\pm 2 \%$ in four independent runs for selected experiments. [d] Average turn-over frequency (TOF/h) during the first $2 \mathrm{~h}$.

14 and 20 versus 24) gives rise to almost the same amount of product formation and the effect of the presence of the Lewis acidic $\mathrm{Al}$ complex is thus minimal. At $90^{\circ} \mathrm{C}$ however, a significant difference in conversion is still noted (compare for instance entries 19 and 23; $42 \%$ versus $17 \%$ ) in line with the hypothesis that the $\mathrm{Al}$ complex under these conditions plays an imperative role. Second, while up to a $90^{\circ} \mathrm{C}$ reaction temperature the selectivity for the cyclic carbonate is maintained ( $\geq 99 \%$ as determined by ${ }^{1} \mathrm{H} \mathrm{NMR}$ ), at $110^{\circ} \mathrm{C}$ in some cases we observed trace amounts of side-products that probably arise from thermal decomposition of the carbonate target. Therefore, because of the above-mentioned reasons further optimization/investigations of the TOF were carried out with $\mathrm{Al}$ complex 8 at a maximum temperature of $90^{\circ} \mathrm{C}$.

Optimization of the performance of Al complex 8 and stability tests: In order to assess the catalytic potential of $\mathrm{Al}$ complex $\mathbf{8}$ in the formation of cyclic carbonates, initial TOFs were then determined at various concentrations of $\mathbf{8}$ (Table 3 ). In each case, a comparison was made between the efficiency of the binary catalyst couple (i.e., $\mathrm{Al}$ complex 8 and $\mathrm{NBu}_{4} \mathrm{I}$ ) versus the co-catalyst alone to ensure that the $\mathrm{Al}$ complex shows a significant contribution in the observed activity. At a loading of $0.05 \mathrm{~mol} \%$ (entry 1, 96\%) a TOF of $960 \mathrm{~h}^{-1}$ is attained, whereas the co-catalyst alone (entry 2 ) shows much lower conversion (17\%). Lowering the loading of Al complex 8 to 0.01 mol\% (entry 3 ) increases the TOF value to $2100 \mathrm{~h}^{-1}$; it is important to note here that the actual potential of a catalyst should be measured at the initial stage of the reaction (i.e., at low conversion levels) when substrate concentration limitation on the observed activity is minimal. When decreasing the amount of $\mathbf{8}$ while maintaining a co-catalyst amount of $0.05 \mathrm{~mol} \%$ very high initial TOFs of $7600 \mathrm{~h}^{-1}$ (entry 5; $0.0025 \mathrm{~mol} \%$ of 8), $16500 \mathrm{~h}^{-1}$ (entry 7; $0.0010 \mathrm{~mol} \%$ of $\mathbf{8}$ ) and $24000 \mathrm{~h}^{-1}$ (entry 8; $0.0005 \mathrm{~mol} \%$ of 8 ) were observed whereas the co-catalyst alone provided a significantly lower conversion (entry $6 ; 13 \%$ ). One of the benchmark systems [Al(salen) dimer A, Scheme 1] from the literature was again compared with our best performing complex $\mathbf{8}$. At a total Al loading of $0.01 \mathrm{~mol} \%$ (entries 3 and 4 in Table 3), catalyst 8 gave an initial TOF $\left(2100 \mathrm{~h}^{-1}\right)$ which is four times higher than observed for dimeric $\mathrm{Al}$ (salen) complex A $\left(550 \mathrm{~h}^{-1}\right)$. Other substrates (14-16) were then tested with $\mathrm{Al}$ complex $\mathbf{8}$ to see whether such high initial TOFs could also be achieved as observed for 1,2-epoxyhexane $\mathbf{1 3}$ (entries 9-11). With these alternative epoxides 14-16 initial TOFs amounted to $27000 \mathrm{~h}^{-1}(\mathbf{1 4}), 24000 \mathrm{~h}^{-1}(\mathbf{1 5})$ and $17000 \mathrm{~h}^{-1}(\mathbf{1 6})$, respectively, demonstrating the wider applicability of catalyst $\mathbf{8}$ and a very high activity in general. As a final part of the optimization of the activity of the binary catalyst couple (Al complex $\mathbf{8}$ and a suitable co-catalyst) we then focused on the use of PPN salts [PPN = bis(triphenylphosphoranylidene)ammonium] of bromide and iodide as these have been shown to give excellent results in the context of (cyclic/poly) carbonate formation. ${ }^{[26]}$ Whereas the use of $\mathrm{Al}$ complex 8/PPN-I (entry 12) showed a modest increase in initial TOF to 29000 $\mathrm{h}^{-1}$ (cf., $24000 \mathrm{~h}^{-1}$ in the case where $\mathrm{NBu}_{4} \mathrm{I}$ was used; entry 8 ), the use of PPN-I alone (entry 13) showed slightly lower conversion of the substrate. The combination of $\mathrm{Al}$ complex $\mathbf{8}$ and $\mathrm{PPN}-\mathrm{Br}$, however, showed significantly higher activity than the co-catalyst alone (compare entries 14 and 15) and a remarkably high initial TOF of $36000 \mathrm{~h}^{-1}$ was achieved.

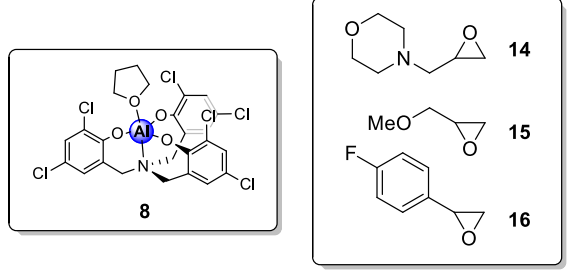

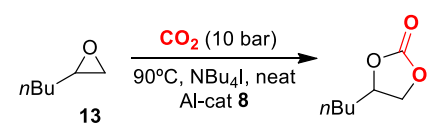

Table 3. Optimization studies towards the activity of Al-catalyst $\mathbf{8}$ in the synthesis of the cyclic carbonates derived from epoxides $13-16$ at $90^{\circ} \mathrm{C}$ using $\mathrm{NBu}_{4} \mathrm{I}$ as co-catalyst and comparison with reactions using only the co-catalyst; Sub refers to substrate. ${ }^{[\mathrm{a}] \mathrm{b}]}$

\begin{tabular}{|c|c|c|c|c|c|}
\hline Entry & $\begin{array}{l}\text { Cat. } 8 \\
\text { (mol\%) }\end{array}$ & $\begin{array}{l}\text { Co-cat. } \\
\text { (mol\%) }\end{array}$ & Sub. & $\begin{array}{l}\text { Conv. } \\
(\%)^{[c]}\end{array}$ & $\begin{array}{l}\text { TOF } \\
\left(\mathrm{h}^{-1}\right)^{[\mathrm{d}]}\end{array}$ \\
\hline 1 & 0.05 & 0.25 & 13 & 96 & 960 \\
\hline 2 & - & 0.25 & 13 & 17 & - \\
\hline 3 & 0.01 & 0.05 & 13 & 42 & 2100 \\
\hline 4 & $0.01^{[\mathrm{e}]}$ & 0.05 & 13 & 11 & 550 \\
\hline 5 & 0.0025 & 0.05 & 13 & 38 & 7600 \\
\hline 6 & - & 0.05 & 13 & 13 & - \\
\hline 7 & 0.0010 & 0.05 & 13 & 33 & 16500 \\
\hline 8 & 0.0005 & 0.05 & 13 & 24 & 24000 \\
\hline 9 & 0.0005 & 0.05 & 14 & 27 & 27000 \\
\hline 10 & 0.0005 & 0.05 & 15 & 24 & 24000 \\
\hline 11 & 0.0005 & 0.05 & 16 & 17 & 17000 \\
\hline 12 & 0.0005 & $0.05^{[f]}$ & 13 & 29 & 29000 \\
\hline 13 & - & $0.05^{[f]}$ & 13 & 21 & - \\
\hline 14 & 0.0005 & $0.05^{[\mathrm{g}]}$ & 13 & 36 & 36000 \\
\hline 15 & - & $0.05^{[\mathrm{g}]}$ & 13 & 19 & - \\
\hline
\end{tabular}

[a] Reaction conditions: epoxide substrate $(10 \mathrm{mmol}), 1.0 \mathrm{MPa} \mathrm{CO}_{2}$ initial pressure, $2 \mathrm{~h}$, $90^{\circ} \mathrm{C}$. [b] Catalyst concentration calculated on a per $\mathrm{Al}$ atom basis and amount related to the substrate. [c] Determined by ${ }^{1} \mathrm{H}$ NMR spectroscopy of the crude reaction mixture; selectivity in all cases $>99 \%$. Conversions were found to be reproducible within $\pm 2 \%$ in four independent runs for selected experiments. [d] Average turn-over frequency (TOF/h) during the first 2 h. [e] Using the North catalyst system A from Scheme 1. [f] Using PPNI as co-catalyst. [g] Using PPN-Br as co-catalyst.

In order to establish the robustness of $\mathrm{Al}$ complex $\mathbf{8}$ several further experiments were conducted. First, at a loading of 0.0005 mol\% of 8 using the conditions reported in entry 8 (Table 3 ) the total turnover number (TON) was determined after $18 \mathrm{~h}$ being a notable 
112000. This shows that the catalyst is stable enough in the course of time at $90^{\circ} \mathrm{C}$ providing further turnover when compared with the initial stage of the reaction (entry $8 ; 2 \mathrm{~h}$ ).

$$
\stackrel{\mathrm{R}^{7}-90^{\circ} \mathrm{C}, \mathrm{NBu}_{4} \mathrm{I},}{\text { neat; Al-cat } 8}
$$<smiles>[R]C1COC(=O)O1</smiles>

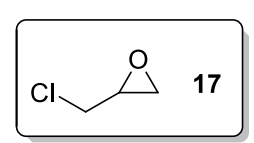

$$
\begin{array}{ll}
\text { 13. } \mathrm{R}=n \mathrm{Bu} & \text { 16. } \mathrm{R}=p-\mathrm{F}-\mathrm{C}_{6} \mathrm{H}_{4} \\
\text { 15. } \mathrm{R}=\mathrm{CH}_{2} \mathrm{OMe} & \text { 17. } \mathrm{R}=\mathrm{CH}_{2} \mathrm{Cl}
\end{array}
$$

\begin{tabular}{|c|c|c|c|c|c|c|}
\hline Entry & $\begin{array}{l}\text { Cat. } 8 \\
\text { (mol\%) }\end{array}$ & $\begin{array}{l}\text { Co-cat. } \\
\text { (mol\%) }\end{array}$ & Substr. & $\begin{array}{l}\text { Time } \\
\text { (h) }\end{array}$ & $\begin{array}{l}\text { Conv. } \\
(\%)^{[c]}\end{array}$ & $\begin{array}{l}\text { TOF } \\
\left(h^{-1}\right)^{[d]}\end{array}$ \\
\hline 1 & 0.0005 & 0.05 & 13 & 0.5 & 6 & 24000 \\
\hline 2 & 0.0005 & 0.05 & 13 & 1 & 13 & 26000 \\
\hline 3 & 0.0005 & 0.05 & 13 & 1.5 & 18 & 24000 \\
\hline 4 & 0.0005 & 0.05 & 13 & 2 & 24 & 24000 \\
\hline 5 & 0.0005 & 0.05 & 13 & 3 & 26 & 17333 \\
\hline 6 & 0.0005 & 0.05 & 13 & 4 & 30 & 15000 \\
\hline 7 & 0.0005 & 0.05 & 13 & 5 & 34 & 13600 \\
\hline 8 & 0.0005 & 0.05 & 13 & 6 & 38 & 12666 \\
\hline 9 & 0.05 & 0.25 & 15 & $18^{[\mathrm{e}]}$ & $99(98)^{[f]}$ & - \\
\hline 10 & 0.05 & 0.25 & 15 & $18^{[\mathrm{g}]}$ & $84(79)^{[f]}$ & - \\
\hline 11 & 0.05 & 0.25 & 16 & $18^{[\mathrm{e}]}$ & $99(92)^{[f]}$ & - \\
\hline 12 & 0.05 & 0.25 & 16 & $18^{[\mathrm{g}]}$ & $99(93)^{[f]}$ & - \\
\hline 13 & 0.05 & 0.25 & 17 & $18^{[\mathrm{e}]}$ & $99(93)^{[f]}$ & - \\
\hline 14 & 0.05 & 0.25 & 17 & $18^{[g]}$ & $91(86)^{[f]}$ & - \\
\hline
\end{tabular}

Table 4. Reactivity in time and stability studies using Al-catalyst $\mathbf{8}$ in the synthesis of cyclic carbonates derived from epoxides 13 and $\mathbf{1 5 - 1 7}$ at $70-90^{\circ} \mathrm{C}$ using $\mathrm{NBu}_{4} \mathrm{I}$ as cocatalyst and comparison with reactions using only the co-catalyst. ${ }^{[a][b]}$

[a] Reaction conditions: epoxide substrate $(10 \mathrm{mmol}), 1.0 \mathrm{MPa} \mathrm{CO}_{2}$ initial pressure, $2 \mathrm{~h}$, $90^{\circ} \mathrm{C}$. [b] Catalyst concentration calculated on a per $\mathrm{Al}$ atom basis and amount related to the substrate. [c] Determined by ${ }^{1} \mathrm{H}$ NMR spectroscopy of the crude reaction mixture; selectivity in all cases $>99 \%$. Conversions were found to be reproducible within $\pm 2 \%$ in four independent runs for selected experiments. [d] Average turn-over frequency (TOF/h) during the first $2 \mathrm{~h}$. [e] At $p\left(\mathrm{CO}_{2}\right)=1 \mathrm{MPa}$ together with $p(\mathrm{Air})=0.2 \mathrm{MPa}$ at $70^{\circ} \mathrm{C}$. [f] In brackets isolated yield. [g] Additionally added $10 \mu \mathrm{L}(5 \mathrm{~mol} \%)$ of water, reaction performed at $70^{\circ} \mathrm{C}$.

Following the average TOF in time (Table 4, entries 1-8) the $\mathrm{TOF} / \mathrm{h}$ stays stable within the first two hours of the reaction and amounts to $12666 \mathrm{~h}^{-1}$ after $6 \mathrm{~h}$; this lower value may be expected when the kinetics of a process follows a non-zero order dependency on the substrate(s) concentration. Then, the stability of the catalyst system was further probed by looking at the turnover under more competitive reaction conditions, i.e. in the presence of air or water (Table 4) and comparing the conversion/yield for three different substrates with those reported previously. ${ }^{[17]}$

Interestingly, the results from entries 9-14 in Table 4 show that neither the presence of air nor water has a dramatic long-term effect (cf., TON) on the conversion of the epoxide nor the isolated yield of the carbonate product with typical yields under these conditions being high (up to 98\%). Therefore, by combining the results from Tables 14 it may be concluded that $\mathrm{Al}$ complex $\mathbf{8}$ is both a highly active as well as robust system that upon combination with a suitable nucleophile $\left(\mathrm{NBu}_{4} \mathrm{X}, \mathrm{PPN}-\mathrm{X} ; \mathrm{X}=\mathrm{Br}, \mathrm{I}\right)$ gives rise to a binary catalyst couple with initial activities amongst the highest reported to date.

Mechanistic considerations: As the mechanism for dimeric $\mathrm{Al}$ (salen) complexes has been recently investigated by North and coworkers, ${ }^{[9 \mathrm{~d}]}$ we have further focused on some of the features of the operative mechanism ${ }^{[27]}$ when using $\mathrm{Al}$ complexes based on aminotris-phenolate scaffolds. Previously, the first step in the $\mathrm{Zn}$ (salphen) catalyzed formation of cyclic carbonates was proposed to be the coordination of the epoxide to the metal center. ${ }^{[9 e, 28]}$ We were able to grow crystals of a similar structure based on Al complex 8 and oxetane, and its structure is presented in Figure 3.

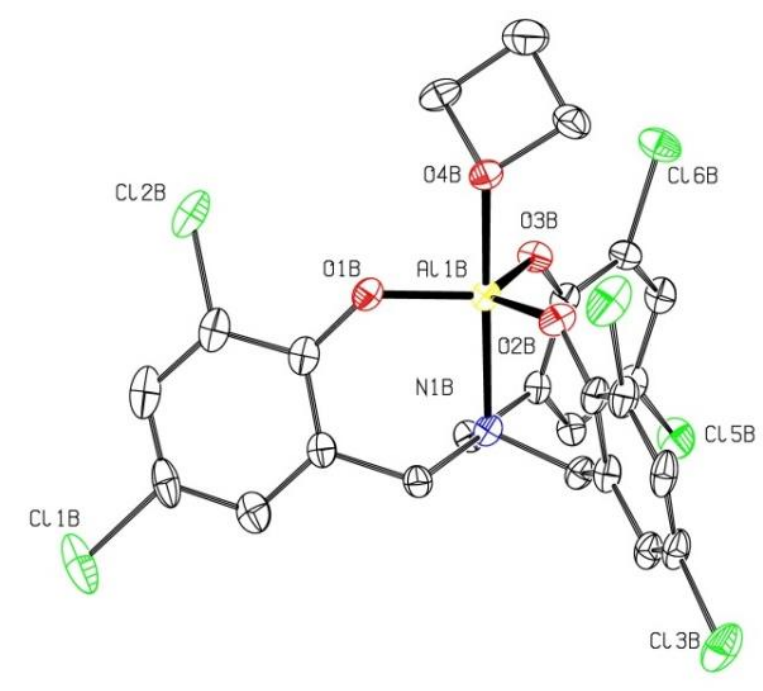

Figure 3. Displacement ellipsoid plot of the structure of 8- oxetane together with a partial numbering scheme. Co-crystallized solvent molecules are omitted for clarity, and only one of the crystallographically independent molecules in the unit cell is shown. Selected bond distances $[\AA]$ and angles $\left[{ }^{\circ}\right]: \mathrm{Al}(1 \mathrm{~B})-\mathrm{O}(1 \mathrm{~B})=1.742(2), \mathrm{Al}(1 \mathrm{~B})-\mathrm{O}(2 \mathrm{~B})=1.759(2)$, $\mathrm{Al}(1 \mathrm{~B})-\mathrm{O}(3 \mathrm{~B})=1.768(2), \mathrm{Al}(1 \mathrm{~B})-\mathrm{O}(4 \mathrm{~B})=1.907(3), \mathrm{Al}(1 \mathrm{~B})-\mathrm{N}(1 \mathrm{~B})=2.073(3) ; \mathrm{O}(1 \mathrm{~B})-$ $\mathrm{Al}(1 \mathrm{~B})-\mathrm{O}(2 \mathrm{~B})=124.84(12), \mathrm{O}(1 \mathrm{~B})-\mathrm{Al}(1 \mathrm{~B})-\mathrm{O}(3 \mathrm{~B})=115.79(11), \mathrm{O}(2 \mathrm{~B})-\mathrm{Al}(1 \mathrm{~B})-\mathrm{O}(4 \mathrm{~B})=$ $84.56(10), \mathrm{O}(1 \mathrm{~B})-\mathrm{Al}(1 \mathrm{~B})-\mathrm{O}(4 \mathrm{~B})=88.67(11), \mathrm{O}(1 \mathrm{~B})-\mathrm{Al}(1 \mathrm{~B})-\mathrm{N}(1 \mathrm{~B})=92.11(12), \mathrm{O}(4 \mathrm{~B})-$ $\mathrm{Al}(1 \mathrm{~B})-\mathrm{N}(1 \mathrm{~B})=175.76(10)$. 


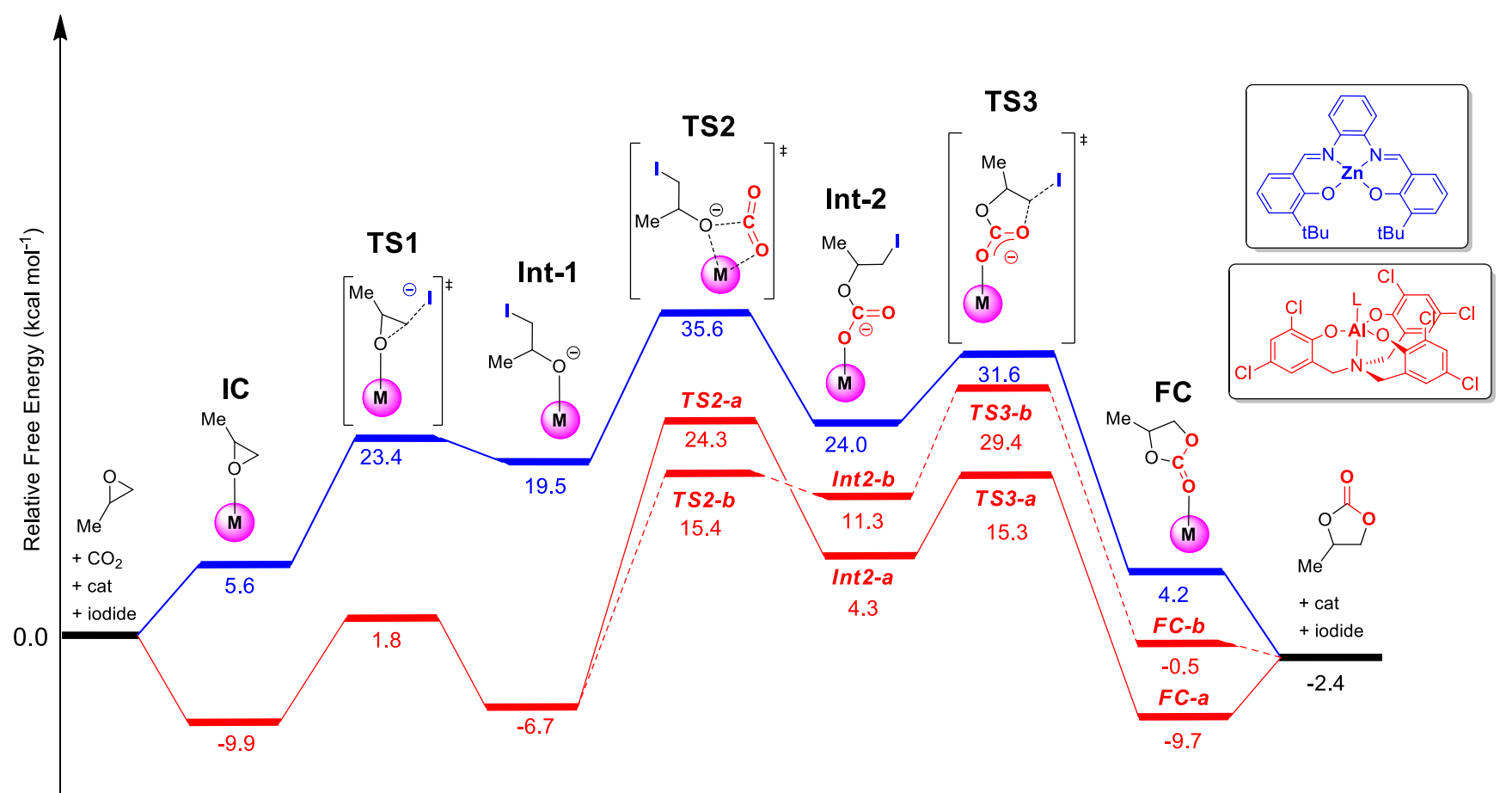

Figure 5. Free-energy profiles for the ring-expansion addition of $\mathrm{CO}_{2}$ to propylene oxide catalyzed by $\mathrm{Zn}(\mathrm{salphen}) / \mathrm{NBu}_{4} \mathrm{I}$ (in blue) and $\mathrm{Al}$-complex $\mathbf{8} / \mathrm{NBu} 4$ (in red) considering the $\beta$ pathway (i.e., initial ring-opening occurs at the non-substituted carbon centre). As solvent MEK was considered at $25^{\circ} \mathrm{C}$. IC stands for initial complex formation; $\mathbf{F C}$ stands for the intermediate complex having the carbonate product coordinated.

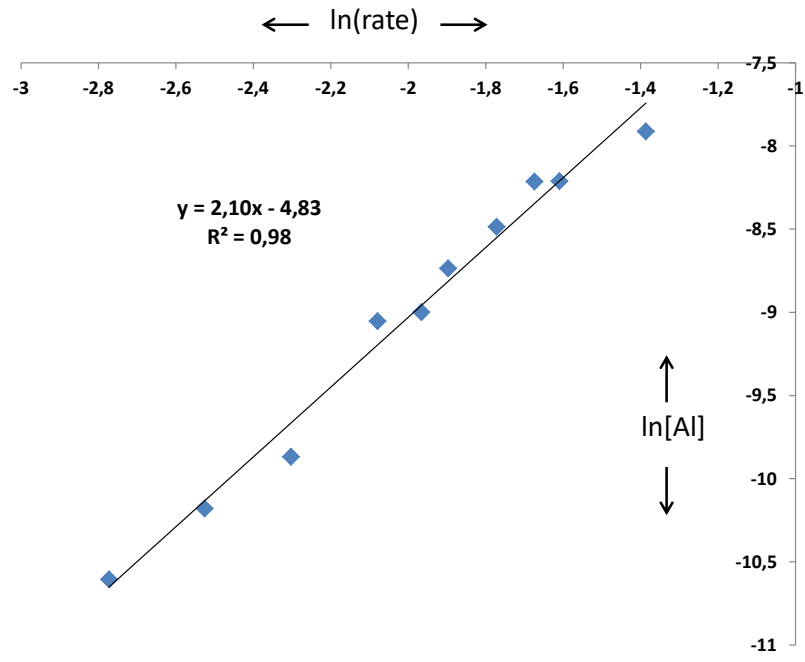

Figure 4. Double logarithmic plot of the order determination in binary catalyst under pseudo steady state conditions using 1,2-epoxyhexane/ $\mathrm{CO}_{2}$ as substrates and different concentrations of the Al-complex 8 at $30^{\circ} \mathrm{C}$.

The structure for $\mathbf{8} \cdot$ oxetane simply serves to demonstrate a likely starting point in the conversion of any substrate converted by the $\mathrm{Al}($ amino-tris-phenolate) complexes reported in this work. Kinetic studies (see experimental section for more details) were performed with the objective to examine the order in the binary catalyst. These kinetic studies were performed with Al complex $\mathbf{8}$ in the range $0.063-0.25 \mathrm{~mol} \%$ (the range wherein most of the experiments were carried out with complexes 5-8 and 12) with respect to the substrate 1,2-epoxyhexane 13 at $30^{\circ} \mathrm{C}$ and an initial $\mathrm{CO}_{2}$ pressure of $1 \mathrm{MPa}(10$ bar) with an iodide loading of $0.5 \mathrm{~mol} \%$. A reaction temperature of $30^{\circ} \mathrm{C}$ was chosen in order to isolate the activity of the binary catalyst system from that of the background conversion related to the cocatalyst which occurs at higher temperatures; the iodide nucleophile itself (at $0.5 \mathrm{~mol} \%$ ) does not lead to any observable conversion at this temperature (separately checked; $0 \%$ conversion). Activity is only observed at $30^{\circ} \mathrm{C}$ when both the Al-complex 8 and the iodide nucleophile are present; the absence of either component results in non-observable formation of product. The results of the kinetic studies are highlighted in Figure 4. The conversion of the substrate was determined by ${ }^{1} \mathrm{H}$ NMR analysis after $2 \mathrm{~h}$ in all experiments by analysing crude reaction mixture aliquots. Interestingly, these kinetic studies appear to reveal a pseudo second order dependence (2.1; Figure 4) on the (binary) catalyst system. The rate law for this process may be written as (equation 1):

$$
\text { Rate }=k \cdot\left[\mathrm{CO}_{2}\right]^{a} \cdot[\text { epoxide }]^{b} \cdot[\mathrm{Al}]^{c} \cdot[\mathrm{I}]^{d}
$$

Here, $k$ represents the rate constant, and $[\mathrm{Al}]$ and $[\mathrm{I}]$ the concentration of complex $\mathbf{8}$ and the iodide, respectively. Assuming steady state conditions at the beginning of the reaction (and thus $\mathrm{CO}_{2}$ and epoxide concentrations being more or less constant) equation 1 can be rewritten as equation 2 :

Rate $=k_{\mathrm{obs}} \cdot[\mathrm{Al}]^{c} \cdot[\mathrm{I}]^{d} \quad$ with $k_{\mathrm{obs}}=k \cdot\left[\mathrm{CO}_{2}\right]^{a} \cdot[\text { epoxide }]^{b}$

Rate $=k_{\text {obs }} \cdot[\text { Cat }]^{e} \quad$ with $[$ Cat $]=$ binary catalyst system $(3)$

Both the Al-complex $\mathbf{8}$ as well as the iodide nucleophile are considered to be equally important for catalytic turnover; they do not act separately and as a result one can assume that $c=d$ and $e=c+d$. Therefore equation 2 can be simplified in the form shown in equation 3. By taking the natural logarithm of equation 3 , equation 4 is obtained: 
$\ln ($ Rate $)=\ln \left(k_{\text {obs }}\right)+e \ln [$ Cat $]$

The kinetic data from the double logarithmic plot revealed that $e$ is close to 2.0 suggesting a (pseudo) second order dependence on the binary catalyst system. As the rate-determining step likely involves the Al-complex $\mathbf{8}$ as well as the iodide, this suggests that only one metal center is actively involved in the mechanistic cycle in contrast with the cycle previously reported for dinuclear $\mathrm{Al}$ (salen) complexes. ${ }^{\left[{ }^{[d]}\right.}$ Also, the computational investigations appear to confirm the requirement of a single Al-complex for effective catalytic turnover as will be discussed below in further detail.

In order to obtain further details about the individual reaction steps and their energy requirements, computational studies were performed using DFT based methods and considering a monometallic mechanism. We recently reported on the computational analysis of the full reaction mechanism based on the binary catalyst $\mathrm{Zn}$ (salphen) $\mathrm{D} / \mathrm{NBu}_{4} \mathrm{I}$ examining various epoxide substrates. ${ }^{[15]} \mathrm{A}$ number of the previously examined substrates ${ }^{[17]}$ converted by Al-complex 8 required methyl ethyl ketone (MEK) as co-solvent, while the former DFT studies (BP86) were carried out with the $\mathrm{Zn}$ (salphen) based catalyst using DCM as medium. Therefore, we have now recalculated the free energies of all transition states (TSs) and intermediates that are involved in the $\mathrm{Zn}($ salphen)/ $\mathrm{NBu} 4$ I catalysed reaction using MEK as medium, and have compared these computational results with those obtained for the binary catalyst system $8 / \mathrm{NBu} 4 \mathrm{I}$ using propylene oxide at $25^{\circ} \mathrm{C}$ at the $\mathrm{B} 3 \mathrm{LYP} / 6$ $311 \mathrm{G} * * / \mathrm{LANL} 2 \mathrm{DZ}$ level of theory (see Figure 5 including schematic representations of the involved intermediates and transition states).

Considering a similar type of monometallic mechanism for both types of catalysts, the reaction starts with coordination of the epoxide (propylene oxide) forming an initial complex IC. Then, the iodide mediates the ring-opening of the coordinated epoxide at the $\beta$ position; this step involves the breaking of the $\mathrm{C}_{\beta}-\mathrm{O}$ bond and the simultaneous formation of a $\mathrm{C}_{\beta}-\mathrm{I}$ bond through TS1 leading to the metal-alkoxide intermediate Int-1. It can be observed that this process is energetically more favourable by $21.6 \mathrm{kcal} \cdot \mathrm{mol}^{-1}$ for Al complex 8 compared to the same step involving the $\mathrm{Zn}$ (salphen) complex. The next step is the insertion of the $\mathrm{CO}_{2}$ molecule into the metal-oxygen bond of intermediate Int-1, leading to the formation of linear carbonate Int-2 through transition state TS2.

Unlike for the $\mathrm{Zn}$ (salphen) catalyst system, for the Al-catalyzed reaction this process involves two likely pathways (i.e., path-a and path-b, see Figure 5). Thus, two TS2 structures could be obtained depending on the relative orientation (cf., axial or equatorial coordination position of $\mathrm{O} 1$ in Figure 6) of the incoming $\mathrm{CO}_{2}$ molecule with respect the metal centre as shown in Figure 6 . Interestingly, in these transition states a hexa-coordinated Al-centre is observed which helps to decrease the energy requirement of the $\mathrm{CO}_{2}$ insertion step. Although TS2-a, and TS2-b are lower in energy than the corresponding transition state for the $\mathrm{Zn}$ (salphen) system by 11.3 and $20.2 \mathrm{kcal} \cdot \mathrm{mol}^{-1}$, respectively, TS2-b would be the most favourable route due to the lower barrier required to afford Int-2b. However, since axial-to-equatorial inter-conversion between intermediates Int2-a and Int2-b should be fairly easy, it is proposed that these species can undergo isomerization. Intermediate Int2-a was found more stable than Int2-b by $7 \mathrm{kcal} \cdot \mathrm{mol}^{-1}$, thus suggesting that the reaction proceeds via path-a. Following the reaction coordinate, the subsequent step is the ring-closing which occurs via the non- coordinating O-atom $(\mathrm{O} 2)$ of the carbonate fragment (Figure 6) through TS3 giving the final intermediate FC. Herein the transition states TS3-a and TS3-b also could afford intermediates FC-a and FC-b, respectively. Thus path-a still continues being the most likely pathway because of the higher stability of TS3-a over TS3-b by 14.1 $\mathrm{kcal} \cdot \mathrm{mol}^{-1}$, and also because the lower absolute value of most other barriers. In addition, path-a has an activation energy of $34.2 \mathrm{kcal} \cdot \mathrm{mol}^{-}$ ${ }^{1}$, with the $\mathrm{CO}_{2}$ insertion being the rate-limiting step; whereas for path-b, a higher activation energy was found $\left(39.3 \mathrm{kcal} \cdot \mathrm{mol}^{-1}\right)$, and the rate-limiting step correspond to the ring-closing. Once the coordinated cyclic carbonate is formed, it is released from the complex allowing for further epoxide turnover. The overall reaction is exergonic with a release of $2.4 \mathrm{kcal} \cdot \mathrm{mol}^{-1}$ in the case of both catalyst systems.

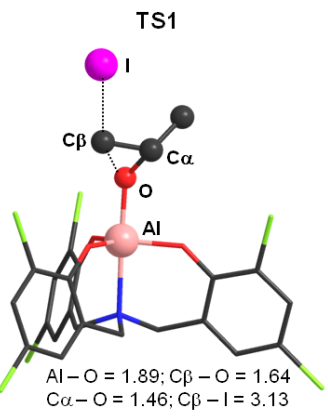

$-243.9 i \mathrm{~cm}^{-1}$

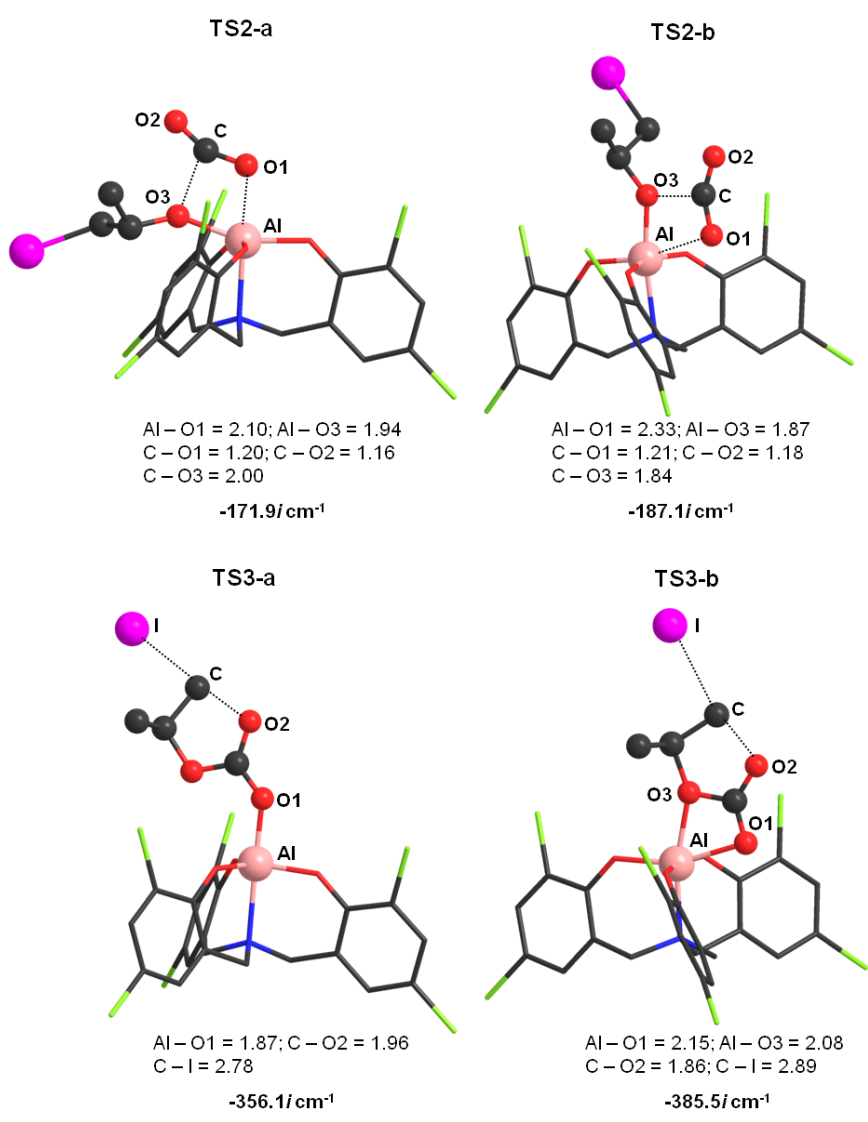

Figure 6. Optimized structures of the transition states TS1-TS3 for the Al-complex 8/ $\mathrm{NBu}_{4} \mathrm{I}$ catalyzed reaction, together with the most relevant calculated distances (in $\AA$ ) and the values of the negative (imaginary) vibrational frequencies.

The competing mechanism was also examined by using the energetic span $(\delta \mathrm{E})$ model. ${ }^{[29]}$ Computed free energy spans for path-a and path-b are fairly high $\left(\delta \mathrm{E}=34.2 \mathrm{kcal} \mathrm{mol}^{-1}\right.$ and $39.3 \mathrm{kcal} \mathrm{mol}^{-1}$, 
respectively); these are identical to the activation barrier of each pathway. IC was found to be the TOF determining intermediate (TDI) for both catalytic cycles, and TS2-a and TS3-b correspond to the TOF determining TS (TDTS) of the alternative cycles. On the other hand, by mixing both pathways (considering the most stable intermediates and TS), a smaller energetic span of $25.3 \mathrm{kcal} \mathrm{mol}^{-1}$ was obtained, where IC is the TDI. However, the exact position of the TDTS is difficult to distinguish because the small difference between TS2-b $\left(15.4 \mathrm{kcal} \mathrm{mol}^{-1}\right)$ and TS3-a $\left(15.3 \mathrm{kcal} \mathrm{mol}^{-1}\right)$. Consequently, a similar degree of TOF control of 0.54 for TS2-b and 0.46 for TS3-a is observed.

The energetic span of the catalytic cycle involving the $\mathrm{Zn}$ (salphen) complex $\mathbf{D}$ was found to be higher $\left(\delta \mathrm{E}=35.6 \mathrm{kcal} \mathrm{mol}^{-}\right.$ $\left.{ }^{1}\right)$ compared to the energetic span of the binary Al-containing catalyst system. The latter, together with the fact that for $\mathrm{Al}$ complex $\mathbf{8}$ all the involved TSs and intermediates are significantly less energydemanding, is in line with the observation that complex $\mathbf{8}$ is a much more efficient catalyst than $\mathrm{Zn}$ (salphen) $\mathbf{D}$ (see also Table 1 for experimental evidence). Of particular note is the fact that the initial coordination of the epoxide in the case of the $\mathrm{Zn}$ (salphen) complex is endothermic $\left(+5.6 \mathrm{kcal} \cdot \mathrm{mol}^{-1}\right)$, while the coordination of propylene oxide to $\mathrm{Al}$ complex 8 is exothermic by $9.9 \mathrm{kcal} \cdot \mathrm{mol}^{-1}$. This result also demonstrates that $\mathbf{8}$ is a much more powerful Lewis acid mediator than $\mathrm{Zn}$ (salphen) complex $\mathbf{D}$.

\section{Conclusion}

In summary, we have reported on a new family of powerful $\mathrm{Al}$ (amino-tris-phenolate) catalysts for the addition of $\mathrm{CO}_{2}$ to epoxides with initial activities among the highest reported to date in this area and turnover numbers exceeding 100000. Furthermore, the most active catalyst based on $\mathrm{Al}$ complex $\mathbf{8}$ is a highly robust system as shown by various stability and activity studies. Kinetic data and DFT calculations appear to support that a monometallic mechanism is likely operative, with the $\mathrm{CO}_{2}$ insertion step being rate-limiting and the initial coordination of the epoxide to the Lewis acidic centre more favourable by around $15 \mathrm{kcal} \cdot \mathrm{mol}^{-1}$ compared to our previous reported $\mathrm{Zn}$ (salphen)/NBu $4 \mathrm{I}$ binary catalyst system. The potential of Al complex 8 to form a less energy-demanding hexa-coordinated transition state is a unique feature (cf., DFT studies) together with its associated lower energetic span are features that help to explain the higher catalytic potential of this system versus the catalyst based on $\mathrm{Zn}$ (salphen) D. The simple access to Al complex 8 and its high potential as a strong Lewis acid mediator make this system a highly potent system for other types of Lewis acid mediated transformations such as the formation of polycarbonates under appropriate conditions. Studies towards this objective are currently ongoing in our laboratory.

\section{Experimental Section}

All epoxide substrates and reagents were commercially available and were used as received. Carbon dioxide was purchased from PRAXAIR and used without further purification. Solvents used in the synthesis of the complexes were dried using an Innovative Technology PURE SOLV solvent purification system. The ligands $\mathbf{1}^{[18]}, \mathbf{2}^{[18]}, \mathbf{3}^{[19]}$ and $\mathbf{4}^{[20]}$ were prepared as described previously although $\mathbf{4}$ was isolated by a modified procedure. The synthesis of $\mathrm{Al}$ (amino-tris-phenolate) complexes was carried out using standard vacuum line and Schlenk or cannular techniques and once synthesized the products were stored in a vial kept in air. ${ }^{1} \mathrm{H}$ NMR spectra were recorded on a Bruker AV-400 or AV-500 spectrometer and referenced to the residual NMR solvent signals. Elemental analysis was performed by the Unidád de Análisis Elemental at the Universidad de Santiago de Compostela. Mass spectrometric analysis and X-ray diffraction studies were performed by the Research Support Group at the ICIQ.

Synthesis of ligand precursor (4): 2,4-dichlorophenol (4.0 g, $24.5 \mathrm{mmol}$ ) and hexamethylene tetramine (HMTA; $1.2 \mathrm{~g}, 8.5 \mathrm{mmol}$ ) were heated at $110^{\circ} \mathrm{C}$ for $2.5 \mathrm{~h}$. Cold $\mathrm{MeOH}(20 \mathrm{~mL})$ was then added to the yellow solution before being kept at $0^{\circ} \mathrm{C}$ for 30 minutes. The solution was sonicated and the precipitate which subsequently formed was filtered off and dried under vacuum. The white solid was found to be a co-crystal with formula 4.HMTA (790 mg, 14\%). Crystals suitable for single crystal X-ray diffraction studies of this cocrystallized adduct were obtained by storing the $\mathrm{MeOH}$ solution at $-30{ }^{\circ} \mathrm{C}$ for a further 3 days. ${ }^{1} \mathrm{H}$ NMR $\left(400 \mathrm{MHz}, 298 \mathrm{~K}, \mathrm{CDCl}_{3}\right): \delta=$ $7.23\left(\mathrm{~d},{ }^{3} J_{\mathrm{HH}}=2.3 \mathrm{~Hz}, 3 \mathrm{H}, \mathrm{Ar} H\right), 7.01\left(\mathrm{~d},{ }^{3} J_{\mathrm{HH}}=2.3 \mathrm{~Hz}, 3 \mathrm{H}, \operatorname{Ar} H\right)$, 6.92 (br s, $3 \mathrm{H}, \mathrm{ArOH}), 4.80\left(\mathrm{~s}, 12 \mathrm{H}, \mathrm{NCH}_{2} \mathrm{~N}\right.$ ), $3.69\left(\mathrm{~s}, 6 \mathrm{H}, \mathrm{ArCH}_{2} \mathrm{~N}\right.$ ); ${ }^{13} \mathrm{C}\left\{{ }^{1} \mathrm{H}\right\} \mathrm{NMR}\left(125 \mathrm{MHz}, 298 \mathrm{~K}, \mathrm{CDCl}_{3}\right): \delta=150.50,129.03$, $128.63,125.22,124.19,121.16$ (all aromatic $C$ ), $74.34\left(\mathrm{NCH}_{2} \mathrm{~N}\right)$, $55.59\left(\mathrm{ArCH}_{2} \mathrm{~N}\right)$; elemental analysis calcd $(\%)$ for $\mathrm{C}_{28} \mathrm{H}_{29} \mathrm{~N}_{5} \mathrm{O}_{3} \mathrm{Cl}_{6}$ : C 47.53, H 3.99, N 10.27; found: C 47.33, H 3.86, N 10.39. The resulting 4.HMTA compound was then suspended in water $(20 \mathrm{~mL})$ and acidified to $\mathrm{pH}=2$ with $\mathrm{HCl}$ ( $37 \%$ in water) whilst stirring before being basified to $\mathrm{pH}=11$, whereby the compound was fully dissolved. The solution was neutralized using $\mathrm{HCl}$, at which point the product precipitated. It was then filtered and dried under vacuum. The resulting yellowish solid was dissolved in a small amount of $\mathrm{CH}_{2} \mathrm{Cl}_{2}$ and hexane added to precipitate the product which was finally filtered and dried to yield a white powder (680 mg, $37 \%)$. ${ }^{1} \mathrm{H}$ NMR (400 $\left.\mathrm{MHz}, 298 \mathrm{~K}, \mathrm{CDCl}_{3}\right): \delta=7.24\left(\mathrm{~d},{ }^{3} J_{\mathrm{HH}}=2.4 \mathrm{~Hz}, 3 \mathrm{H}, \mathrm{Ar} H\right), 7.04(\mathrm{~d}$, $\left.{ }^{3} J_{\mathrm{HH}}=2.4 \mathrm{~Hz}, 3 \mathrm{H}, \mathrm{ArH}\right), 5.53($ br s, $3 \mathrm{H}, \mathrm{ArOH}), 3.73(\mathrm{~s}, 6 \mathrm{H}$, $\left.\mathrm{ArCH}_{2} \mathrm{~N}\right) ;{ }^{13} \mathrm{C}\left\{{ }^{1} \mathrm{H}\right\}$ NMR $\left(125 \mathrm{MHz}, 298 \mathrm{~K}, \mathrm{CDCl}_{3}\right): \delta=149.83$, 129.10, 128.54, 124.84, 124.72, 121.09 (all aromatic $C$ ), 55.35 $\left(\mathrm{ArCH}_{2} \mathrm{~N}\right.$ ); MS (ESI, MeOH): $\mathrm{m} / z$ (calcd): $540.9[M]^{+}$; found: 541 . elemental analysis calcd (\%) for $\mathrm{C}_{21} \mathrm{H}_{15} \mathrm{NO}_{3} \mathrm{Cl}_{6}: \mathrm{C} 46.53, \mathrm{H} 2.79, \mathrm{~N}$ 2.58; found: C 46.73, H 2.73, N 2.57.

Synthesis of Al complex (5): ${ }^{[22 a]}$ To a solution of ligand precursor $1(1.0 \mathrm{~g}, 2.38 \mathrm{mmol})$ in THF $(20 \mathrm{~mL})$ was slowly added $\mathrm{AlMe}_{3}$ (2M in heptane, $1.19 \mathrm{~mL}, 2.38 \mathrm{mmol}$ ). The solution was stirred at r.t. for $2 \mathrm{~h}$ and then concentrated. Hexane was added to the concentrate resulting in precipitation of the complex which was isolated by filtration and further dried under vacuum to yield a white powder (963 mg, 78\%). ${ }^{1} \mathrm{H} \mathrm{NMR}\left(400 \mathrm{MHz}, 298 \mathrm{~K}, \mathrm{CDCl}_{3}\right): \delta=6.90$ $\left(\mathrm{d},{ }^{3} J_{\mathrm{HH}}=1.4 \mathrm{~Hz}, 3 \mathrm{H}, \operatorname{Ar} H\right), 6.63\left(\mathrm{~d},{ }^{3} J_{\mathrm{HH}}=1.4 \mathrm{~Hz}, 3 \mathrm{H}, \operatorname{Ar} H\right), 4.59$ (br s, 4H, THF), 4.28 (br d, ${ }^{2} J_{\mathrm{HH}}=13.5 \mathrm{~Hz}, 3 \mathrm{H}, \mathrm{ArCH}_{2} \mathrm{~N}$ ), 2.86 (br d, $\left.{ }^{2} J_{\mathrm{HH}}=13.5 \mathrm{~Hz}, 3 \mathrm{H}, \mathrm{ArCH}_{2} \mathrm{~N}\right), 2.22\left(\mathrm{~s}, 9 \mathrm{H}, \mathrm{ArCH}_{3}\right), 2.21(\mathrm{~s}, 9 \mathrm{H}$, $\left.\mathrm{ArCH}_{3}\right), 2.18$ (br s, 4H, THF); ${ }^{13} \mathrm{C}\left\{{ }^{1} \mathrm{H}\right\}$ NMR $(125 \mathrm{MHz}, 298 \mathrm{~K}$, $\mathrm{CDCl}_{3}$ ): $\delta=154.29,131.02,126.97,126.89,125.83,120.63$ (all aromatic C), 71.31 (THF), $58.67\left(\mathrm{ArCH}_{2} \mathrm{~N}\right), 25.60$ (THF), 20.40 $\left(\mathrm{ArCH}_{3}\right), 16.98\left(\mathrm{ArCH}_{3}\right)$; MS (MALDI+, detb): $\mathrm{m} / z$ (calcd): 443.2 $[M-\mathrm{THF}]^{+}$; found: 443 .

Synthesis of Al complex (6): ${ }^{[22 b]}$ This compound was prepared in a similar manner to 5 by treatment of ligand precursor $\mathbf{2}(1.0 \mathrm{~g}, 1.49$ mmol) with $\mathrm{AlMe}_{3}(2 \mathrm{M}$ in heptane, $0.75 \mathrm{~mL}, 1.49 \mathrm{mmol}$ ) to yield a white powder ( $869 \mathrm{mg}, 76 \%) .{ }^{1} \mathrm{H} \mathrm{NMR}\left(400 \mathrm{MHz}, 298 \mathrm{~K}, \mathrm{CDCl}_{3}\right): \delta$ $=7.25\left(\mathrm{~d},{ }^{3} J_{\mathrm{HH}}=2.5 \mathrm{~Hz}, 3 \mathrm{H}, \mathrm{ArH}\right), 6.87\left(\mathrm{~d},{ }^{3} J_{\mathrm{HH}}=2.5 \mathrm{~Hz}, 3 \mathrm{H}, \mathrm{Ar} H\right)$, 4.36 (br s, 1H, THF), 4.33 (br s, 3H, THF $\mathrm{ArCH}_{2} \mathrm{~N}$ ), 4.27 (br s, $3 \mathrm{H}$, THF), 2.95 (br s, 3H, $\mathrm{ArCH}_{2} \mathrm{~N}$ ), 2.06 (m, 4H, THF), 1.43 (s, 27H, 
$\left.\operatorname{ArC}\left(\mathrm{CH}_{3}\right)_{3}\right), 1.29\left(\mathrm{~s}, 27 \mathrm{H}, \operatorname{ArC}\left(\mathrm{CH}_{3}\right)_{3}\right) ;{ }^{13} \mathrm{C}\left\{{ }^{1} \mathrm{H}\right\} \mathrm{NMR}(125 \mathrm{MHz}$, $\left.298 \mathrm{~K}, \mathrm{CDCl}_{3}\right): \delta=154.82,139.37,137.11,123.78,123.60,121.43$ (all aromatic $C$ ), 70.26 (THF), $58.83\left(\mathrm{ArCH}_{2} \mathrm{~N}\right), 34.88\left(\mathrm{ArC}\left(\mathrm{CH}_{3}\right)_{3}\right)$, $34.03\left(\mathrm{ArC}\left(\mathrm{CH}_{3}\right)_{3}\right), 31.71\left(\mathrm{ArC}\left(\mathrm{CH}_{3}\right)_{3}\right), 29.70\left(\mathrm{ArC}\left(\mathrm{CH}_{3}\right)_{3}\right), 25.42$ (THF); MS (MALDI+, dctb): $\mathrm{m} / z$ (calcd): $695.5[M-\mathrm{THF}]^{+}$; found: 695.

Synthesis of Al complex (7): This compound was prepared in a similar manner to $\mathbf{5}$ by treatment of ligand precursor $\mathbf{3}(350 \mathrm{mg}, 1.04$ mmol) with $\mathrm{AlMe}_{3}(2 \mathrm{M}$ in heptane, $0.51 \mathrm{~mL}, 1.04 \mathrm{mmol})$ to yield a white powder $(286 \mathrm{mg}, 76 \%) .{ }^{1} \mathrm{H} \mathrm{NMR}(400 \mathrm{MHz}, 298 \mathrm{~K}$, [D $\mathrm{D}_{5}$ ]pyridine): $\delta=7.37$ (ddd, ${ }^{3} \mathrm{~J}_{\mathrm{HH}}=7.6$ and $7.7,{ }^{4} J_{\mathrm{HH}}=1.5 \mathrm{~Hz}, 3 \mathrm{H}$, $\operatorname{Ar} H), 7.18\left(\mathrm{dd},{ }^{3} J_{\mathrm{HH}}=7.6,{ }^{4} J_{\mathrm{HH}}=1.5 \mathrm{~Hz}, 3 \mathrm{H}, \mathrm{Ar} H\right), 7.06\left(\mathrm{dd},{ }^{3} J_{\mathrm{HH}}=\right.$ $\left.7.7,{ }^{4} J_{\mathrm{HH}}=0.9 \mathrm{~Hz}, 3 \mathrm{H}, \mathrm{Ar} H\right), 6.92\left(\mathrm{ddd},{ }^{3} J_{\mathrm{HH}}=7.6\right.$ and $7.7,{ }^{4} J_{\mathrm{HH}}=$ $0.9 \mathrm{~Hz}, 3 \mathrm{H}, \mathrm{ArH}$ ), 4.49 (br s, $3 \mathrm{H}, \mathrm{ArCH}_{2} \mathrm{~N}$ ), 3.14 (br s, $3 \mathrm{H}, \mathrm{ArCH}_{2} \mathrm{~N}$ ); ${ }^{13} \mathrm{C}\left\{{ }^{1} \mathrm{H}\right\}$ NMR (125 MHz, $298 \mathrm{~K},\left[\mathrm{D}_{5}\right]$ pyridine): $\delta=160.21,130.77$, 130.52, 123.50, 120.69, 119.09 (all aromatic C), $59.46\left(\mathrm{ArCH}_{2} \mathrm{~N}\right)$ MS (MALDI+, dctb): $\mathrm{m} / \mathrm{z}$ (calcd): $359.11[\mathrm{M}]^{+}$; found: 359.4; elemental analysis calcd (\%) for $\mathrm{C}_{21} \mathrm{H}_{18} \mathrm{NO}_{3} \mathrm{Al} \cdot \mathrm{H}_{2} \mathrm{O} \cdot 1 / 4\left(\mathrm{C}_{6} \mathrm{H}_{14}\right)$ : C 67.74, H 5.94, N 3.51; found: C 67.41, H 5.95, N 3.25.

Synthesis of Al complex (8): This compound was prepared in a similar manner to 5 by treatment of ligand precursor $4(500 \mathrm{mg}, 0.92$ mmol) with $\mathrm{AlMe}_{3}(2 \mathrm{M}$ in heptane, $0.46 \mathrm{~mL}, 0.92 \mathrm{mmol}$ ) to yield a white powder $(350 \mathrm{mg}, 60 \%)$. Crystals suitable for single crystal Xray diffraction studies were obtained by layering of a concentrated THF solution of the complex with hexane. ${ }^{1} \mathrm{H}$ NMR $(400 \mathrm{MHz}, 298$ $\left.\mathrm{K}, \mathrm{CDCl}_{3}\right): \delta=7.33\left(\mathrm{~d},{ }^{3} J_{\mathrm{HH}}=2.6 \mathrm{~Hz}, 3 \mathrm{H}, \mathrm{Ar} H\right), 6.90\left(\mathrm{~d},{ }^{3} J_{\mathrm{HH}}=2.6\right.$ $\mathrm{Hz}, 3 \mathrm{H}, \operatorname{Ar} H), 4.69$ (m, 4H, THF), 4.18 (br d, ${ }^{2} J_{\mathrm{HH}}=13.3 \mathrm{~Hz}, 3 \mathrm{H}$, $\left.\mathrm{ArCH}_{2} \mathrm{~N}\right), 2.95\left(\mathrm{br} \mathrm{d},{ }^{2} J_{\mathrm{HH}}=13.3 \mathrm{~Hz}, 3 \mathrm{H}, \mathrm{ArCH}_{2} \mathrm{~N}\right), 2.23(\mathrm{~m}, 4 \mathrm{H}$, THF); ${ }^{13} \mathrm{C}\left\{{ }^{1} \mathrm{H}\right\}$ NMR $\left(125 \mathrm{MHz}, 298 \mathrm{~K}, \mathrm{CDCl}_{3}\right): \delta=152.46,129.75$, 127.13, 124.68, 123.08, 122.16 (all aromatic $C$ ), 72.38 (THF), 58.25 ( $\mathrm{ArCH}_{2} \mathrm{~N}$ ), 25.48 (THF); MS (MALDI+, dctb): $\mathrm{m} / \mathrm{z}$ (calcd): 564.9 [M - $\mathrm{THF}]^{+}$; found: 565; elemental analysis calcd (\%) for $\mathrm{C}_{25} \mathrm{H}_{20} \mathrm{AlCl}_{6} \mathrm{NO}_{4}$ : C 47.05, H 3.16, N 2.19; found: C 46.75, H 3.22, N 2.12.

Synthesis of ligand precursor (11): To a solution of 6,6'(azanediyl-bis(methylene))-bis(2,4-di-tert-butylphenol) (0.80 g, 1.76 $\mathrm{mmol}$ ) and 2-(bromomethyl)-4-nitrophenol (204 mg, $1.76 \mathrm{mmol}$ ) in THF $(20 \mathrm{~mL})$, was added with stirring $\mathrm{NEt}_{3}(123 \mu \mathrm{L}, 1.76 \mathrm{mmol})$. The reaction mixture was stirred at reflux temperature for $18 \mathrm{~h}$ and filtered after cooling. The volatiles were removed from the filtrate and the obtained residue was purified by column chromatography (EtOAc:hexane, 20:80 v/v) to yield a yellow powder (721 mg, 68\%). ${ }^{1} \mathrm{H} \mathrm{NMR}\left(400 \mathrm{MHz}, 298 \mathrm{~K}, \mathrm{CDCl}_{3}\right): \delta=8.04\left(\mathrm{dd},{ }^{3} J_{\mathrm{HH}}=8.9 \mathrm{~Hz},{ }^{4} J_{\mathrm{HH}}\right.$ $=2.8 \mathrm{~Hz} 1 \mathrm{H}, \operatorname{Ar} H), 7.96\left(\mathrm{~d},{ }^{4} J_{\mathrm{HH}}=2.8 \mathrm{~Hz}, 1 \mathrm{H}, \operatorname{Ar} H\right), 7.24\left(\mathrm{~d},{ }^{4} J_{\mathrm{HH}}=\right.$ $2.4 \mathrm{~Hz}, 2 \mathrm{H}, \operatorname{Ar} H), 6.98\left(\mathrm{~d},{ }^{4} J_{\mathrm{HH}}=2.4 \mathrm{~Hz}, 2 \mathrm{H}, \operatorname{Ar} H\right), 6.86\left(\mathrm{~d},{ }^{3} J_{\mathrm{HH}}=\right.$ $8.9 \mathrm{~Hz}, 1 \mathrm{H}, \mathrm{ArH}$ ), 5.91 (br s, $3 \mathrm{H}, \mathrm{ArOH}), 3.85$ (s, $2 \mathrm{H}, \mathrm{ArCH}_{2} \mathrm{~N}$ ), 3.78 $\left(\mathrm{s}, 4 \mathrm{H}, \quad \operatorname{ArCH}_{2} \mathrm{~N}\right), 1.41\left(\mathrm{~s}, 18 \mathrm{H}, \operatorname{ArC}\left(\mathrm{CH}_{3}\right)_{3}\right), 1.28(\mathrm{~s}, 18 \mathrm{H}$, $\left.\operatorname{ArC}\left(\mathrm{CH}_{3}\right)_{3}\right) ;{ }^{13} \mathrm{C}\left\{{ }^{1} \mathrm{H}\right\}$ NMR $\left(125 \mathrm{MHz}, 298 \mathrm{~K}, \mathrm{CDCl}_{3}\right): \delta=162.40$, $151.31,142.59,140.41,135.92,126.45,125.69,125.62,124.20$, 123.19, 121.68, 116.73 (all aromatic $C$ ), 57.68, 56.94 (both $\mathrm{ArCH}_{2} \mathrm{~N}$ ), 34.60, 34.19 (both $\left.\operatorname{ArC}\left(\mathrm{CH}_{3}\right)_{3}\right), 31.55,29.88$ (both $\left.\operatorname{ArC}\left(\mathrm{CH}_{3}\right)_{3}\right)$; MS (ESI-, MeOH): $\mathrm{m} / \mathrm{z}$ (calcd) $603.4[\mathrm{M}-\mathrm{H}]^{-}$; found: 603; elemental analysis calcd (\%) for $\mathrm{C}_{37} \mathrm{H}_{52} \mathrm{~N}_{2} \mathrm{O}_{5} \cdot 1 / 2 \mathrm{H}_{2} \mathrm{O}: \mathrm{C} 72.40, \mathrm{H}$ 8.70, N 4.56; found: C 72.57, $\mathrm{H} 8.63, \mathrm{~N} 4.47$.

Synthesis of Al complex (12): This compound was prepared in a similar manner to $\mathbf{5}$ by treatment of $\mathbf{1 1}(500 \mathrm{mg}, 0.82 \mathrm{mmol})$ with $\mathrm{AlMe}_{3}(2 \mathrm{M}$ in heptane, $0.41 \mathrm{~mL}, 0.82 \mathrm{mmol}$ ) to yield a white powder (422 mg, 78\%). Crystals suitable for single crystal X-ray diffraction studies were obtained by layering of a concentrated THF solution of the complex with hexane. ${ }^{1} \mathrm{H}$ NMR (400 MHz, $298 \mathrm{~K}$, [D 5 ]pyridine): $\delta=8.27\left(\mathrm{dd},{ }^{3} J_{\mathrm{HH}}=8.9,{ }^{4} J_{\mathrm{HH}}=2.8 \mathrm{~Hz}, 1 \mathrm{H}, \operatorname{Ar} H\right), 8.13\left(\mathrm{~d},{ }^{4} J_{\mathrm{HH}}=2.8\right.$ $\mathrm{Hz}, 1 \mathrm{H}, \operatorname{Ar} H), 7.51\left(\mathrm{~d},{ }^{4} J_{\mathrm{HH}}=2.3 \mathrm{~Hz}, 2 \mathrm{H}, \operatorname{Ar} H\right), 7.12(\mathrm{br} \mathrm{s}, 2 \mathrm{H}, \operatorname{Ar} H)$, $7.03\left(\mathrm{~d},{ }^{3} J_{\mathrm{HH}}=8.9 \mathrm{~Hz}, 1 \mathrm{H}, \mathrm{ArH}\right), 4.15\left(\mathrm{br} \mathrm{s}, 3 \mathrm{H}, \mathrm{ArCH}_{2} \mathrm{~N}\right), 3.25(\mathrm{br}$ $\left.\mathrm{s}, 3 \mathrm{H}, \mathrm{ArCH}_{2} \mathrm{~N}\right), 1.43\left(\mathrm{~s}, 18 \mathrm{H}, \operatorname{ArC}\left(\mathrm{CH}_{3}\right)_{3}\right), 1.34\left(\mathrm{~s}, 18 \mathrm{H}, \operatorname{ArC}\left(\mathrm{CH}_{3}\right)_{3}\right)$; ${ }^{13} \mathrm{C}\left\{{ }^{1} \mathrm{H}\right\}$ NMR (125 MHz, $298 \mathrm{~K},\left[\mathrm{D}_{5}\right]$ pyridine): $\delta=165.44,155.13$, $139.77,139.07,137.48,135.53,125.82,125.75,124.30,123.70$, 123.53, 119.59 (all aromatic C), 58.83, 56.90 (both $\mathrm{ArCH}_{2} \mathrm{~N}$ ), 34.61, 34.11 (both $\left.\operatorname{ArC}\left(\mathrm{CH}_{3}\right)_{3}\right), 31.71,29.52$ (both $\left.\operatorname{ArC}\left(\mathrm{CH}_{3}\right)_{3}\right) ; \mathrm{m} / \mathrm{z}$ (calcd) $628.35[\mathrm{M}]^{+}$; found: 628.4; elemental analysis calcd $(\%)$ for $\mathrm{C}_{37} \mathrm{H}_{49} \mathrm{~N}_{2} \mathrm{O}_{5} \mathrm{Al} \cdot \mathrm{H}_{2} \mathrm{O} \cdot 1 / 2\left(\mathrm{C}_{6} \mathrm{H}_{14}\right): \mathrm{C} 69.64, \mathrm{H} 8.47, \mathrm{~N} 3.91$; found: $\mathrm{C}$ $69.59, \mathrm{H} 8.78$, N 3.80 .

Typical catalysis procedure: $1.0 \mathrm{~g}$ of 1,2-epoxyhexane, 0.005 mol\% of aluminium complex and $0.025 \mathrm{~mol} \% \mathrm{Bu} 4 \mathrm{NI}$ were charged into a $30 \mathrm{~mL}$ stainless steel autoclave. The autoclave was then subjected to three cycles of pressurization and depressurization with $\mathrm{CO}_{2}$ (0.5 MPa, $5 \mathrm{bar}$ ), before final stabilization of the pressure to 1.0 MPa (10 bar). The autoclave was sealed and heated to the required temperature and left stirring for $2 \mathrm{~h}$. An aliquot of the resulting mixture was taken and conversion analyzed by means of ${ }^{1} \mathrm{H}$ NMR spectroscopy using $\mathrm{CDCl}_{3}$ as the solvent. The identity of the cyclic carbonate product was confirmed by comparison to previously reported literature values. For a photo of the reactor please refer to the Supporting Information.

Kinetic experiments: The AMTEC vessels were charged with $\mathrm{NBu}_{4} \mathrm{I}$ and connected to the hardware. A leak test was first performed with $1.5 \mathrm{MPa}$ ( $15 \mathrm{bar}$ ) of $\mathrm{CO}_{2}$, with the pressure finally reduced to 0.2 $\mathrm{MPa}(2 \mathrm{bar})$. The reactors were filled with $0.4 \mathrm{MPa}$ (4 bar) of $\mathrm{CO}_{2}$, and degassed to 2 bar, and this cycle was repeated three times. A solution of the $\mathrm{Al}$ catalyst $\mathbf{8}$ in $1.20 \mathrm{ml}$ of 1,2-epoxyhexane $\mathbf{1 3}$ was injected into the reaction vessel, the pressure was raised to $1.5 \mathrm{MPa}$ (15 bar), and the temperature was set to $30^{\circ} \mathrm{C}$. The reactions were stirred for $2 \mathrm{~h}$ at $600 \mathrm{rpm}$. The stirrer was then stopped and degassed. Hereafter, an aliquot of the resultant reaction mixture was taken and the conversion was determined by means of ${ }^{1} \mathrm{H}$ NMR spectroscopy using $\mathrm{CDCl}_{3}$ as the solvent. For a photo of the reactor system please refer to the Supporting Information.

X-ray diffraction studies: The measured crystals were stable under atmospheric conditions; nevertheless they were treated under inert conditions immersed in perfluoropolyether as protecting oil for manipulation. Data Collection: Measurements were made on a Bruker-Nonius diffractometer equipped with an APPEX $24 \mathrm{~K} \mathrm{CCD}$ area detector, a FR591 rotating anode with $\mathrm{MoK} \alpha$ radiation, Montel mirrors and a Kryoflex low temperature device $\left(\mathrm{T}=-173{ }^{\circ} \mathrm{C}\right)$. Fullsphere data collection was used with $\omega$ and $\varphi$ scans. Programs used: Data collection Apex2 V2011.3 (Bruker-Nonius 2008), data reduction Saint + Version 7.60A (Bruker AXS 2008) and absorption correction SADABS V. 2008-1 (2008). Structure Solution: SHELXTL Version 6.10 (Sheldrick, 2000) was used. Structure Refinement: SHELXTL-97-UNIX VERSION.

Crystallographic details for Al-complex 8-THF: Formula $\mathrm{C}_{25} \mathrm{H}_{20} \mathrm{Cl}_{6} \mathrm{NO}_{4} \mathrm{Al} ; \mathrm{M} w=638.10$; crystal size $0.30 \times 0.15 \times 0.05 \mathrm{~mm}^{3}$; orthorhombic; space group Pbca; $a=17.2360(19) \AA, b=15.7823(17)$ $\AA, c=19.047(2) \AA ; \alpha=\beta=\gamma=90.0^{\circ} ; V=5181.2(10)^{\circ} ; Z=8 ; \rho_{\text {calcd }}=$ $1.636 \mathrm{mg} / \mathrm{M}^{3} ; \mu(\mathrm{MoK} \alpha)=0.733 \mathrm{~mm}^{-1} ; T=100(2) \mathrm{K} ; \theta(\min / \max )=$ 2.05/26.25; $F(000)=2592 ; 93683$ reflections collected; 5209 unique reflections $\left(R_{\mathrm{int}}=0.0535\right)$; absorption correction empirical; 
refinement method: full-matrix least-squares on $F^{2}$; data/restraints/ parameters: $5209 / 86 / 364 ; \mathrm{GoF}$ on $F^{2}=1.074 ; R_{1}=0.0287$ and $w R_{2}=$ $0.0663[\mathrm{I}>2 \sigma(\mathrm{I})] ; R_{1}=0.0404$ and $w R_{2}=0.0728$ (all data); largest diff. peak and hole: 0.333 and $-0.305 \mathrm{e}^{3} \cdot \AA^{-3}$. CCDC 902502 contains the supplementary crystallographic data for this structure. These data can be obtained free of charge from The Cambridge Crystallographic Data Centre via www.ccdc.cam.ac.uk/data_request/cif.

Crystallographic details for Al-complex 12: Formula $\mathrm{C}_{95} \mathrm{H}_{122} \mathrm{~N}_{4} \mathrm{O}_{10} \mathrm{Al}_{2} ; \mathrm{M} w=1533.93 ;$ crystal size $0.15 \times 0.05 \times 0.05$ $\mathrm{mm}^{3}$; monoclinic; space group $P 2(1) / \mathrm{c} ; a=29.417(3) \AA ⿻$ 10.9419(12) $\AA, c=30.189(3) \AA ; \alpha=\gamma=90^{\circ}, \beta=118.896(4)^{\circ} ; V=$ $8507.2(17)^{\circ} ; Z=4 ; \rho_{\text {calcd }}=1.198 \mathrm{mg} / \mathrm{M}^{3} ; \mu(\operatorname{MoK} \alpha)=0.095 \mathrm{~mm}^{-1} ; T$ $=100(2) \mathrm{K} ; \theta(\min / \max )=0.79 / 24.80 ; F(000)=3304 ; 79528$ reflections collected; 14140 unique reflections $\left(R_{\text {int }}=0.1388\right)$; absorption correction empirical; refinement method: full-matrix least-squares on $F^{2}$; data/restraints/ parameters: 14140/441/1127; GoF on $F^{2}=1.015 ; R_{1}=0.0643$ and $w R_{2}=0.1280[\mathrm{I}>2 \sigma(\mathrm{I})] ; R_{1}=$ 0.1523 and $w R_{2}=0.1658$ (all data); largest diff. peak and hole: 0.546 and $-0.554 \mathrm{e}^{3} \cdot \AA^{-3}$. This structure is a toluene solvate and has a tertbutyl group disordered. CCDC 938872 contains the supplementary crystallographic data for this structure. These data can be obtained free of charge from The Cambridge Crystallographic Data Centre via www.ccdc.cam.ac.uk/data_request/cif.

Crystallographic details for Al-complex 8-oxetane: Formula $\mathrm{C}_{25} \mathrm{H}_{19.75} \mathrm{NO}_{4.25} \mathrm{Cl}_{6.75} \mathrm{Al} ; \mathrm{M} w=668.44 ;$ crystal size $0.50 \times 0.05 \times 0.05$ $\mathrm{mm}^{3}$; triclinic; space group $P-1 ; a=13.702(4) \AA, b=14.048(4) \AA, c$ $=14.784(3) \AA ; \alpha=94.689(7), \beta=93.252(7), \gamma=100.374(10)^{\circ} ; V=$ $2782.5(12)^{\circ} ; Z=4 ; \rho_{\text {calcd }}=1.596 \mathrm{mg} / \mathrm{M}^{3} ; \mu(\mathrm{MoK} \alpha)=0.757 \mathrm{~mm}^{-1} ; T$ $=100(2) \mathrm{K} ; \theta(\min / \max )=1.39 / 28.23 ; F(000)=1354 ; 21763$ reflections collected; 21763 unique reflections $\left(R_{\text {int }}=0.000\right)$; absorption correction empirical; refinement method: full-matrix least-squares on $F^{2}$; data/restraints/ parameters: 21763/72/758; GoF on $F^{2}=1.021 ; R_{1}=0.0570$ and $w R_{2}=0.1528[\mathrm{I}>2 \sigma(\mathrm{I})] ; R_{1}=0.0928$ and $w R_{2}=0.1898$ (all data); largest diff. peak and hole: 0.881 and $-0.940 \mathrm{e}^{3} \cdot \AA^{-3}$. The disorder in co-crystallized solvent molecules and the coordinated oxetane was done with TWINABS. ${ }^{[30]}$ CCDC 938873 contains the supplementary crystallographic data for this structure. These data can be obtained free of charge from The Cambridge Crystallographic Data Centre via www.ccdc.cam.ac.uk/data_request/cif.

The structure for 4.HMTA can be found in the Supporting Information, CCDC 938871 contains the supplementary crystallographic data for this structure.

Computational details: All calculations were performed by using the Gaussian 09 package $^{[31]}$ with the hybrid B3LYP functional. ${ }^{[32]}$ The standard $6-311 \mathrm{G}(\mathrm{d}, \mathrm{p})$ basis set was used to describe the $\mathrm{H}, \mathrm{C}, \mathrm{N}$ and $\mathrm{O}$ atoms. The relativistic effective core pseudo potential LANL2DZ was used, together with its associated basis set, for $\mathrm{Al}, \mathrm{Zn}, \mathrm{Cl}$ and I atoms. Full geometry optimizations were performed without constrains. The nature of the stationary points encountered was characterized either as minima or transition states by means of harmonic vibrational frequencies analysis. The zeropoint, thermal, and entropy corrections were evaluated to compute enthalpies and Gibbs free energies ( $T=298 \mathrm{~K}, p=1 \mathrm{bar})$. Solvent effects for MEK have been introduced by using the Polarizable Continuum Model (PCM).

\section{Acknowledgements}

We thank ICIQ, ICREA, the the Spanish Ministry of Science and Innovation (MINECO, projects CTQ-2011-27385 and CTQ2011-29054-C02-02 and FPI to FCG) and Generalitat de Catalunya (project 2009-SGR-259) for support. We acknowledge Dr. Noemí Cabello, Vanessa Martínez, and Sofía Arnal for performing the MS studies.

[1] a) Carbon Dioxide as Chemical Feedstock (Ed.: M. Aresta), Wiley-VCH, Weinheim, 2010; b) M. Peters, B. Köhler, W. Kuckshinrichs, W. Leitner, P. Markewitz, T. E. Müller, ChemSusChem 2011, 4, 1216-1240; c) M. Cokoja, C. Bruckmeier, B. Rieger, W. A. Herrmann, F. E. Kühn, Angew. Chem. Int. Ed. 2011, 50, 8510-8537; d) T. Sakakura, J. C. Choi, H. Yasuda, Chem. Rev. 2007, 107, 2365-2387; e) R. Martín, A. W. Kleij, ChemSusChem 2011, 4, 1259-1263.

[2] See for instance: a) G. Pagani, Hydrocarbon Process. 1982, 61, 87-91; b) Refer also to www.novomer.com for a company focusing on green polymer synthesis using $\mathrm{CO}_{2}$ as a feedstock.

[3] a) E. A. Quadrelli, J.-L. Duplan, G. Centi, S. Perathoner, ChemSusChem 2011, 4 , 1194-1215; b) G. Centi, G. Iaquaniello, S. Perathoner, ChemSusChem 2011, 4, $1265-1273$.

[4] For some original recent examples: a) C. Das Neves Gomes, O. Jacquet, C. Villiers, P. Thuéry, M. Ephritikhine, T. Cantat, Angew. Chem. Int. Ed. 2012, 51 , 187-190; b) T. Kimura, K. Kamata, N. Mizuno, Angew. Chem. Int. Ed. 2012, 51 , 6700-6703; c) A. Decortes, A. W. Kleij, ChemCatChem 2011, 3, 831-834; d) I. I. F. Boogaerts, S. P. Nolan, J. Am. Chem. Soc. 2010, 132, 8858-8859; e) D. R. Dalton, T. Rovis, Nat. Chem. 2010, 2, 710-711; f) A. Correa, R. Martín, J. Am. Chem. Soc. 2009, 131, 15974-15975; g) T. Fujihara, K. Nogi, T. Xu, J. Terao, Y. Tsuji, J. Am. Chem. Soc. 2012, 134, 9106-9109; h) M. R. Kember, C. K. Williams, J. Am. Chem. Soc. 2012, 134, 15676-15679; i) S. Wesselbaum U. Hintermair, W. Leitner, Angew. Chem. Int. Ed. 2012, 51, 8585-8588; j) A. Monassier, V. D'Elia, M. Cokoja, J. Pelletier, J.-M. Basset, F. E. Kühn, ChemCatChem 2013, 5, 13211324 .

[5] a) D. J. Darensbourg, Inorg. Chem. 2010, 49, 10765-10780; b) D. J. Darensbourg, Chem. Rev. 2007, 107, 2388-2410; c) M. R. Kember, A. Buchard, C. K. Williams, Chem. Commun. 2011, 47, 141-163; d) G. W. Coates, D. R. Moore, Angew. Chem. Int. Ed. 2004, 43, 6618-6639; e) X.-B- Lu, D. J. Darensbourg, Chem. Soc. Rev. 2012, 41, 1462-1484; e) G.-P. Wu, W.-M. Ren, Y. Luo, B. Li, W.-Z. Zhang, X.B. Lu, J. Am. Chem. Soc. 2012, 134, 5682-5688

[6] a) M. North, R. Pasquale and C. Young, Green Chem. 2010, 12, 1514-1539; b) A Decortes, A. M. Castilla, A. W. Kleij, Angew. Chem. Int. Ed. 2010, 49, 98229837; c) P. P. Pescarmona, M. Taherimehr, Catal. Sci. Technol. 2012, 2, 2169 2187.

[7] The often used term "cyclo" addition reaction is in our view incorrect as it formally refers to a pericyclic chemical conversion between one or more unsaturated molecules. This combination should then give a cyclic product with a net reduction of the bond multiplicity.

[8] a) J. Sun, S.-I. Fujita, M. Arai, J. Organomet. Chem. 2005, 690, 3490-3497; b) Y. Zhao, C. Yao, G. Chen, Q. Yuan, Green. Chem. 2013, 15, 446-452; c) Z.-Z. Yang, L.-N. He, C.-X. Miao, S. Chanfreau, Adv. Synt. Catal. 2010, 352, 2233-2240.

[9] a) R. L. Paddock, S. T. Nguyen, Chem Commun. 2004, 1622; b) C. Whiteoak, E. Martin, M. Martínez Belmonte, J. Benet-Buchholz, A. W. Kleij, Adv. Synth. Catal. 2012, 354, 469-476; c) R. M. Haak, A. Decortes, E. C. Escudero-Adán, M. Martínez Belmonte, E. Martin, J. Benet-Buchholz, A. W. Kleij, Inorg. Chem. 2011, 50, 7934-7936; d) M. North, R. Pasquale, Angew. Chem. Int. Ed. 2009, 48 , 2946-2948; e) A. Decortes, M. Martínez Belmonte, J. Benet-Buchholz, A. W. Kleij, Chem. Commun. 2010, 46, 4580-4582; f) J. Langanke, L. Greiner, W. Leitner, Green Chem. 2013, 15, 1173-1182.

[10] a) A. Buchard, M. R. Kember, K. G. Sandeman, C. K. Williams, Chem. Commun. 2011, 47, 212-214; b) T. Ema, Y. Miyazaki, S. Koyama, Y. Yano, T. Sakai, Chem. Commun. 2012, 48, 4489-4491; c) M. V. Escárcega-Bobadilla, M. Martínez Belmonte, E. Martin, E. C. Escudero-Adán, A. W. Kleij, Chem. Eur. J. 2013, 19 , 2641-2648; d) J. Meléndez, M. North, P. Villuendas, C. Young, Dalton Trans. 2011, 40, 3885-3902; e) M. A. Fuchs, T. A. Zevaco, E. Ember, O. Walter, I. Held, E. Dinjus, M. Döring, Dalton Trans. 2013, 42, 5322-5329.

[11] V. Caló, A. Nacci, A. Monopoli, A. Fanizzi, Org. Lett. 2002, 4, 2561-2563.

[12] For the synthesis of cyclic carbonates using a flue gas based feedstock: M. North, B. Wang, and C. Young, Energy Environ. Sci. 2011, 4, 4163-4170.

[13] a) C. J. Whiteoak, B. Gjoka, E. Martin, M. Martínez Belmonte, E. C. EscuderoAdán, C. Zonta, G. Licini, A. W. Kleij, Inorg. Chem. 2012, 51, 10639-10649; b) G. Licini, M. Mba, C. Zonta, Dalton Trans. 2009, 5265-5277.

[14] For some recent reviews on salen chemistry and systems see for example: a) C. J. Whiteoak, G. Salassa, A. W. Kleij, Chem. Soc. Rev. 2012, 41, 622-631; b) A. W. Kleij, Chem. Eur. J. 2008, 14, 10520-10529. 
[15] F. Castro-Gómez, G. Salassa, A. W. Kleij, C. Bo, Chem. Eur. J. 2013, 19, 62896298

[16] a) W. Clegg, R. W. Harrington, M. North, R. Pasquale, Chem. Eur. J. 2010, 16, 6828-6843; b) D. Tian, B. Liu, Q. Gan, H. Li, D. J. Darensbourg, ACS Catal. 2012, 2, 2029-2035.

[17] C. J. Whiteoak, N. Kielland, V. Laserna, E. C. Escudero-Adán, E. Martin, A. W. Kleij, J. Am. Chem. Soc. 2013, 155, 1228-1231.

[18] a) A. Chandrasekaran, R. O. Day, R. R. Holmes, J. Am. Chem. Soc. 2000, 122 1066-1072; b) M. Kol, M. Shamis, I. Goldberg, Z. Goldschmidt, S. Alfi, E. HayutSalant, Inorg. Chem. Commun. 2001, 4, 177-179.

[19] L. J. Prins, M. Mba, A. Kolarović, G. Licini, Tetrahedron Lett. 2006, 47, 2735 2738.

[20] S. Groysman, I. Goldberg, M. Kol, E. Genizi, Z. Goldschmidt, Adv. Synth. Catal. $\mathbf{2 0 0 5}, 347,409$

[21] X. Zhang, D. H. Solomon, Polymer 1998, 39, 405-412.

[22] a) A. L. Johnson, M. G. Davidson, Y. Pérez, M. D. Jones, N. Merle, P. R. Raithby, S. P. Richards, Dalton Trans. 2009, 5551-5558; b) J. Zhang, A. Liu, X. Pan, L. Yao, L. Wang, J. Fang, J. Wu, Inorg. Chem. 2011, 50, 9564-9570. For some catalytic applications of Lewis acidic $\mathrm{Al}($ amino-tris-phenolates) see: c) S. M Raders, J. G. Verkade, J. Org. Chem. 2009, 74, 5417-5428; d) S. M. Raders, J. G. Verkade, Tetrahedron Lett. 2009, 50, 5317-5321.

[23] I. S. Belostotskaya, N. L. Komissarova, T. I. Prokof'eva, L. N. Kurkovskaya, V. B. Vol'eva, Russian J. Org. Chem. 2005, 41, 703-706.

[24] Note that a comparison between catalysts at higher conversion levels does not necessarily imply the best evaluation of the relative catalyst potential. This should be done at the early stage of the reactions (i.e., at low conversions) where initial TOFs give a better description of the potential of a catalyst.

[25] C. Beattie, M. North, P. Villuendas, C. Young, J. Org. Chem. 2013, 78, 419-426.

[26] For illustrative examples: a) W.-M. Ren, G.-P. Wu, F. Lin, J.-Y. Jiang, C. Liu, Y Luo, X.-B. Lu, Chem. Sci. 2012, 3, 2094-2102; b) A. Berkessel, M. Brandenburg, Org. Lett. 2006, 8, 4401-4404; c) D. J. Darensbourg, S. J. Wilson, J. Am. Chem. Soc. 2011, 133, 18610-18613.
[27] For an early discussion around fundamental mechanistic features in $\mathrm{CO}_{2}$ chemistry refer to: W. Leitner, Coord. Chem. Rev. 1996, 153, 257-284.

[28] M. Taherimehr, A. Decortes, S. M. Al-Amsyar, W. Lueangchaichaweng, C. J Whiteoak, A. W. Kleij, P. P. Pescarmona, Catal. Sci. Technol. 2012, 2, 2231 2237.

[29] a) S. Kozuch, S. Shaik, Acc. Chem. Res. 2011, 44, 101-110; b) A. Uhe, S. Kozuch, S. Shaik, Comput. Chem. 2011, 32, 978-985; c) S. Kozuch, WIREs Comput Mol Sci 2012, 2, 795-815; See also: d) Uhe, M. Hölscher, W. Leitner, Chem. Eur. J. 2012, 18, 170-177 for the use of the energetic span model in $\mathrm{CO}_{2}$ chemistry.

[30] TWINABS version 2008/4, Bruker AXS; R. H. Blessing, Acta Cryst. 1995, A51, 33-38.

[31] Gaussian 09, Revision A.02, M. J. Frisch, G. W. Trucks, H. B. Schlegel, G. E. Scuseria, M. A. Robb, J. R. Cheeseman, G. Scalmani, V. Barone, B. Mennucci, G. A. Petersson, H. Nakatsuji, M. Caricato, X. Li, H. P. Hratchian, A. F. Izmaylov, J. Bloino, G. Zheng, J. L. Sonnenberg, M. Hada, M. Ehara, K. Toyota, R. Fukuda, J. Hasegawa, M. Ishida, T. Nakajima, Y. Honda, O. Kitao, H. Nakai, T. Vreven, J. A. Montgomery, Jr., J. E. Peralta, F. Ogliaro, M. Bearpark, J. J. Heyd, E. Brothers, K. N. Kudin, V. N. Staroverov, R. Kobayashi, J. Normand, K Raghavachari, A. Rendell, J. C. Burant, S. S. Iyengar, J. Tomasi, M. Cossi, N. Rega, J. M. Millam, M. Klene, J. E. Knox, J. B. Cross, V. Bakken, C. Adamo, J. Jaramillo, R. Gomperts, R. E. Stratmann, O. Yazyev, A. J. Austin, R. Cammi, C. Pomelli, J. W. Ochterski, R. L. Martin, K. Morokuma, V. G. Zakrzewski, G. A Voth, P. Salvador, J. J. Dannenberg, S. Dapprich, A. D. Daniels, Ö. Farkas, J. B. Foresman, J. V. Ortiz, J. Cioslowski, and D. J. Fox, Gaussian, Inc., Wallingford CT, 2009.

[32] a) A. D. Becke, J. Chem. Phys. 1993, 98, 5648-5652; b) C. Lee, R. G. Parr, W Yang, Phys. Rev. B 1988, 37, 785-789.

Received: ((will be filled in by the editorial staff)) Revised: ((will be filled in by the editorial staff)) Published online: ((will be filled in by the editorial staff)) 
Strong Lewis Acids

Christopher J. Whiteoak, Nicola Kielland, Victor Laserna, Fernando Castro-Gómez, Eddy Martin, Eduardo C. Escudero-Adán, Carles Bo, and Arjan W. Kleij*... Page - Page

Highly Active Aluminium Catalysts for the Ring-Expansion Addition of $\mathrm{CO}_{2}$ to Oxiranes

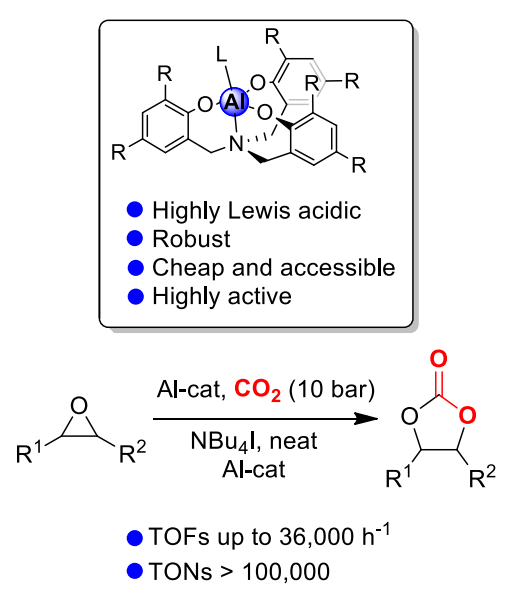

$\mathrm{Al}^{\mathrm{III}}$ derived complexes from readily accessible amino tris-phenolate ligands show exceptional catalytic reactivity in the addition of $\mathrm{CO}_{2}$ to epoxides affording cyclic carbonates with high initial turnover frequencies of up to $36,000 \mathrm{~h}^{-1}$ and TONs exceeding 100,000. A combined experimental and computational approach has been used to unveil the key features of these highly robust and attractive catalysts in the context of organic carbonate formation. 